This is the accepted manuscript. It is published by ASCE Library and can be found online at https:// doi.org/10.1061/9780784414422.ch25 
CHAPTER 25

\title{
Anaerobic Membrane Bioreactors for Future Green Bioprocesses
}

\author{
Wenshan Guo, Huu Hao Ngo, Cheng Chen, Ashok Pandey, Kuo-Lun \\ Tung and Duu-Jong Lee
}

\subsection{Introduction}

With ever-increasing consumption and pollution of our limited water resources, water scarcity has been brought rising levels of public concern on a global scale. However, this worsening situation could be alleviated through sustainable water reuse schemes, which include using suitable wastewater treatment technologies to treat and reclaim wastewater. Starting from the last century, anaerobic wastewater treatment technology has been recognized as a more promising alternative to conventional aerobic bioprocesses due to its prime advantages in pollution reduction, net energy production (methane generation) and sludge minimization. To date, anaerobic treatment processes have been successfully utilized for treating agricultural and industrial sewages, particularly in the mesophilic or thermophilic temperature conditions.

Nevertheless, the applicability of anaerobic bioprocesses has been proven to be limited with the major concern on poor biomass retention. In the conventional anaerobic digestion processes, the slow-growing nature of methanogenic microbes together with the poor settling properties of the biomass lead to a low yield of net biomass production and the loss of biomass to the effluent (Lin et al. 2013). As a result, anaerobic effluent can rarely meet the standards for water reuse and aerobic treatment or other processes are usually required as a post-treatment to further polish the effluent from anaerobic processes (Chan et al. 2009).

As advanced membrane-based separations are well suited for water recycling and reuse, membrane bioreactor (MBR) technology is now experiencing rapid growth in a wide variety of applications and has become one of the most promising technologies for the $21^{\text {st }}$ century. Being an alternative to the conventional activated sludge (CAS)-membrane filtration process by combining both activated sludge process and membrane separation into one single unit, MBRs can provide superior 
performance such as high effluent quality, excellent microbial separation ability, absolute control of hydraulic retention time (HRT) and sludge retention time (SRT), high biomass content and less sludge bulking problem, relatively low-rate sludge production, small footprint and limited space requirement and possibilities for a flexible and phased extension of existing wastewater treatment plants (Ngo et al. 2012).

To solve the problems associated with poor retention of anaerobic microbes in conventional anaerobic treatment processes and high energy requirement in aerobic MBRs owing to aeration, anaerobic membrane bioreactor (AnMBR) technology has been considered as an attractive approach. The main advantages of AnMBR include higher biomass retention to attain a full growth of slow-growing methanogenic consortia and probability of bioenergy recovery, thereby improving treatment and energy efficiency. Moreover, compared with conventional anaerobic processes that require large capacity reactors to hold the slow-growing anaerobic microorganisms, AnMBR processes can operate with a significantly reduced reactor footprint to ensure efficient anaerobic biodegradation of nutrients, suspended solids, colloidal organics, bacteria, etc., as well as achieve sustainable biosolids management. However, membrane fouling of AnMBR remains as a main impediment to its worldwide application, and its economic consequences deserve serious consideration when applying AnMBR technology, in terms of plant maintenance/operation as well as membrane cleaning and replacement (Lew et al. 2009; Yoo et al. 2012; Lin et al. 2013).

As membrane fouling has been extensively reviewed by many researchers, this chapter mainly focuses on the comprehensive overview of the recent progress in AnMBR applications, including the fundamental aspects and development of AnMBR processes. As a future green bioprocess, biogas production and waste minimization, opportunities, future perspectives and research needs are also discussed.

\subsection{Fundamentals of AnMBR}

\subsubsection{Evolution of AnMBR Technology}

The very first concept of AnMBR technology was proposed by Hans E. Grethlein in 1978 in Hanover, New Hampshire, USA, when a flat sheet ultrafiltration (UF) membrane module and a Helicore reverse osmosis (RO) unit were used to treat effluent from a septic tank. The flow was directed to one or two modules in parallel, and the concentrated solution was returned back to the septic tank (Grethlein 1978). Based on the patented Membrane Sewage Treatment System (MSTS), Dorr-Oliver Inc., USA has developed the first commercially-available AnMBR (the Membrane anaerobic Reactor System (MARS)) in 1984, which was composed of an activated sludge reactor followed by an UF step for solid-liquid separation under anaerobic operation (Li et al. 1985). In 1985, a 6-year R\&D program was initiated in Japan in order to develop various pilot-scale AnMBR systems by utilizing different kinds of 
membranes and bioreactor configurations (suspended growth and attached growth) for industrial wastewater and sewage treatment (Kimura 1991). During 1987 and 1988, research on combining anaerobic digestion with locally manufactured UF membranes has been carried out in South Africa to treat wine distillery wastewater with high chemical oxygen demand (COD). After that, a number of pilot- and fullscale systems, known as Anaerobic Digestion Ultrafiltration (ADUF) systems, have been implemented successfully for treatment of organic industrial effluents (Ross et al. 1990).

Since then, research and investigations on AnMBRs have been focused on membrane materials, filtration performance, membrane fouling characterization and strategies for fouling control (Lin et al. 2013). In the last decade, Kubota submerged Anaerobic Membrane Biological Reactor (KSAMBR) has been proposed by Kubota Corporation, Japan, which has been successfully applied in 15 full-scale plants (Kanai et al. 2010). As reported by McMahon (2010), the largest AnMBR system in the world is the ADI-AnMBR developed by ADI Systems, Inc. in cooperation with Kubota. Table 25.1 lists the important milestones of AnMBR development and applications. At present, the focus of AnMBR research has been mainly on energy recovery, nutrient recovery, membrane fouling control and application implementation.

Table 25.1. The milestones of AnMBRs' evolution

\begin{tabular}{|c|c|c|}
\hline Year & Highlights & Reference \\
\hline 1978 & $\begin{array}{l}\text { The first AnMBR application achieved the reduction of E. coli, } \\
\text { turbidity, BOD, nitrate and orthophosphate by } 100,100,85-95 \text {, } \\
72-75 \text { and } 24-85 \text {, prospectively. } \\
\text { - The anaerobic digestion rate of organic carbon in the septic tank } \\
\text { was enhanced by } 3-4 \text { times due to the increased concentration of } \\
\text { microorganisms and substrate caused by membrane. } \\
\text { - The stability of pH was excellent even with intermittent loading } \\
\text { and the sludge accumulation was less than that in the ordinary } \\
\text { septic tank. } \\
\text { - High practical flux ( } 400 \text { to } 600 \mathrm{~L} / \mathrm{m}^{2} \cdot \mathrm{d} \text { with UF module for over } \\
900 \text { pump hours or } 1500 \text { hours of real time without frequent } \\
\text { cleaning of the membrane. }\end{array}$ & $\begin{array}{l}\text { Grethlein } \\
1978\end{array}$ \\
\hline 1985 & $\begin{array}{l}\text { The first commercially available AnMBR - pilot-scale MARS, } \\
\text { was developed for treating dairy and wheat starch wastewater. } \\
\text { The system was capable of removing } 95.1 \text { and } 99.2 \% \text { of COD at } \\
\text { a volumetric loading of } 14.6 \text { and } 8 \mathrm{kgCOD} / \mathrm{m}^{3} \cdot \mathrm{d}, \mathrm{respectively} \text {. } \\
\text { - SS were well handled by this process and less than } 10 \mathrm{mg} / \mathrm{L} \\
\text { effluent SS was obtained with influent } \mathrm{SS} \text { up to } 13,300 \mathrm{mg} / \mathrm{L} \text {. } \\
\text { - The average observed methane yield rate varied from } 0.28 \text { to } \\
0.34 \mathrm{~m}^{3} \mathrm{CH} 4 / \mathrm{kg} \text { COD removed. }\end{array}$ & $\begin{array}{l}\text { Li et al. } \\
1985\end{array}$ \\
\hline
\end{tabular}


- Pilot-scale ADUF was completely enclosed non-odor process and has been applied for food-processing and beverage wastewater treatment.

- For the digester, no strict SRT control and complete mixing were required. Sludge could be withdrawn from the digester and

Ross et al. 1990 returned to the external UF unit at different levels.

- It was also highlighted that ADUF was a high-rate process with high space load rates $\left(>10 \mathrm{kgCOD} / \mathrm{m}^{3} \cdot \mathrm{d}\right)$, which led to reduced digester volume and capital cost.

- Based on ADUF process, pilot- and full-scale BIOREK ${ }^{\circledR}$ system has been developed by BIOSCAN Engineering A/S, Denmark to treat pig manure. The system comprised six unit operations (preseparation, the ADUF process, ammonia stripping process, RO, gas purification and power generation).

1999

- More than $80 \%$ of water was recovered from the slurry and more than $90 \%$ COD was removed through the mesophilic anaerobic digestion reaction with a HRT of 6 days.

Norddahl and Rohold 2000

- Results from full-scale plant showed that it was possible to produce energy from biogas recovery and fertilizer from potassium and phosphate recovery, as well as potable demineralized water.

- KSAMBR process has been successfully applied in a number of full-scale food and beverage industries, which consisted of a solubilization tank and a thermophilic or mesophilic digestion tank coupled with submerged membranes.

- One of the main advantages of KSAMBR is that membranes retain the methanogenic bacteria while dissolved methane Kanai et al. fermentation inhibitors (e.g. ammonia) are filtered out with the 2010 permeate. The digester volumes can be scaled down to $1 / 3$ to $1 / 5$ of the conventional digesters due to concentrated biomass.

- COD removal efficiency was between 75 to $92 \%$ and the biogas $\left(60 \% \mathrm{CH}_{4}\right.$ and $40 \% \mathrm{CO}_{2}$ with a few minor components such as $\mathrm{H}_{2} \mathrm{~S}$ ) generated could be utilized for water heating via boilers.

- ADI-AnMBR has been applied in Ken's Foods of Marlborough, MA, USA for upgrading one of its three WWTPs in order to maximize biogas production and treat high-strength organic content wastewater, containing high levels of fat, oil and grease.

- The ADI-AnMBR system can remove 99.4\% COD and produce effluent free of SS, allowing $378 \mathrm{~m}^{3} / \mathrm{d}$ treated water to be discharged into the municipal system.

McMahon

- As part of the system upgrade, the AnMBR has been operated 2010 together with previously installed low-rate anaerobic reactor (developed by ADI). The combined system produces approximately $5660-8500 \mathrm{~m}^{2}$ biogas every day, which can not only satisfy $100 \%$ heating requirements of the WWTPs, but also provide more than $50 \%$ of power supply for the company's manufacturing facility.

BOD: biological oxygen demand; COD: chemical oxygen demand; RO: reverse osmosis; SS: suspended solids; WWTP: wastewater treatment plant 


\subsubsection{Membrane and Process Design}

An AnMBR can be defined as a biological treatment process, which is operated without the presence of oxygen and using a membrane to achieve complete retention of microorganisms and solid-liquid separation. However, Liao et al. (2006) discussed in their critical review that this definition is too broad because there are a wide variety of alternatives existed for both the anaerobic process and the membrane process. The effectiveness of AnMBRs is usually dependent upon which alternatives are adopted in the process design. Therefore, it would be useful to overview the current available alternatives before looking into the process design of AnMBRs.

Available anaerobic reactors can be generally classified into two categories based on the criteria whether there is biomass retention. Continuous stirred tank reactor (CSTR) is a classic example of reactor designs that do not provide biomass retention. In this case, the HRT remains the same as the SRT in CSTR and hence suspended solids concentration of the effluent remains the same as the solids concentration in the bulk reaction zone. This type of reactor is mainly utilized in treating high solids wastes including sludge from municipal wastewater treatment systems and animal manures and food processing wastewater. On the other hand, the most commonly recognized reactors that offer biomass retention are upflow anaerobic sludge bed (UASB), anaerobic filter (AF), expanded granular sludge bed (EGSB), fluidized bed (FB), etc. In this case, the suspended solids concentration in the effluent is dramatically reduced as compared with that in the reactor ozone (Liao et al. 2006).

Membranes used in anaerobic treatment can be classified into metallic, polymeric and inorganic (ceramic) based on what material used to manufacture membrane. Ceramic membranes have been used most extensively in the early studies of AnMBRs due to less membrane fouling and their ability of being backwashed without affecting their longevity adversely. As for metallic membranes, they can demonstrate better fouling recovery, higher endurance to an impact force, and tolerance to high temperature and oxidation. Moreover, it has been observed that both metallic and ceramic membranes show their advantages in better hydraulic performance and easier fouling control over polymeric membranes. However, they cost much more compared to polymeric counterparts. Therefore, polymeric membranes have attracted more interests in both research and commercial development of AnMBR, especially when the economic concern becomes the major consideration for the commercialization of a system in the recent years. Regarding the membrane materials, the preferred ones are polyvinylidene fluoride (PVDF) and polyethersulfone (PES) which present a significant fraction of the total products on the market (75\%) (Skouteris et al. 2012; Lin et al. 2013). Commonly, microfiltration (MF, $0.1-10 \mu \mathrm{m})$ and UF $(0.01-0.1 \mu \mathrm{m})$ membranes are the most popular membranes used for AnMBRs with three common configurations, namely hollow fiber, flat sheet (plate or frame) and tubular. The key features of each type can be found in the book chapter of Guo and Ngo (2012). 
The AnMBR configurations are generally divided into two major groups depending upon whether membrane operation is under vacuum or under pressure. For those requiring a pump to push anaerobic bioreactor effluent to the membrane unit and permeate through the membrane, they are normally called external crossflow AnMBR (Fig.25.1a), of which the membrane system is separated from anaerobic bioreactor. AnMBR can also be operated under a vacuum to draw effluent through membrane and this configuration is often named submerged AnMBR (SAnMBR). In this case, the membrane could be either directly placed in the anaerobic bioreactor (Fig.25.1b) or immersed in a separated bioreactor (Fig.25.1c).

Early studies of AnMBR have been focused on the external configuration exclusively. However, this configuration has its own inherent weaknesses. First of all, extensive energy consumption due to the high hydraulic shear force reduces the economic efficiency of AnMBR applications (Choo and Lee 1998; Stuckey 2012). The high shear force can also cause the disruption of anaerobic biosolids, leading to aggravated membrane fouling and harming the biological activities of anaerobic microbes. Compared to external configuration, submerged types can have substantial energy savings because no recirculation pump is required. Thus, SAnMBR has become a promising alternative due to its relatively lower energy consumption, fewer rigorous cleaning procedures, and milder operational conditions with lower tangential velocities (Brockman and Seyfried 1996; Lin et al. 2013).

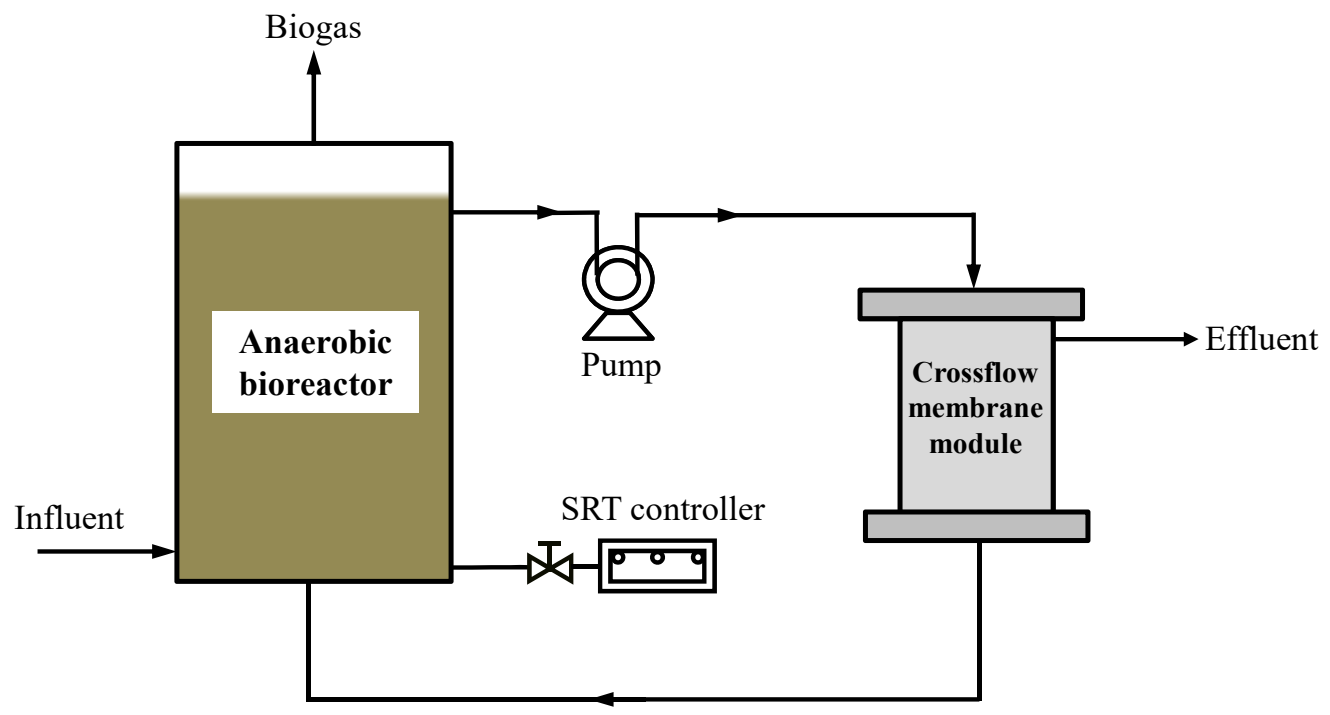

(a) External crossflow AnMBR 


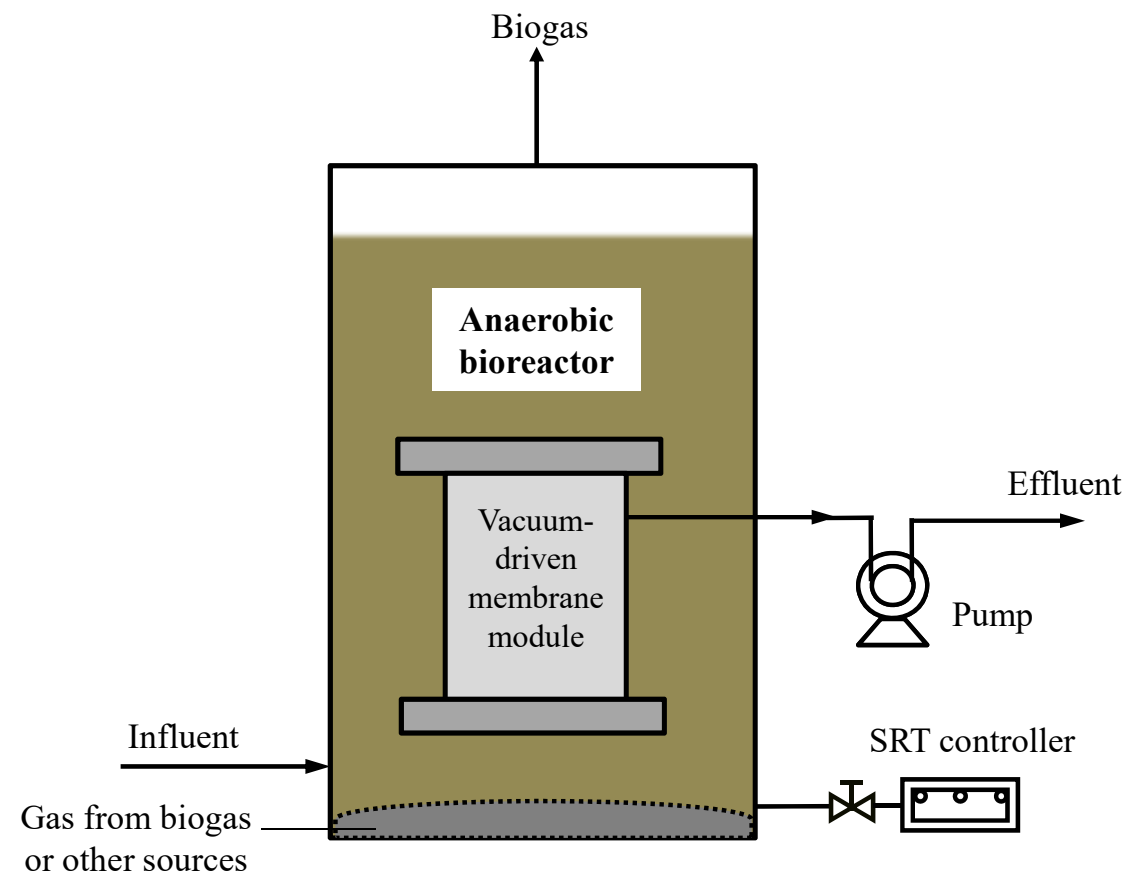

(b) SAnMBR with the membrane placed directly in the reactor

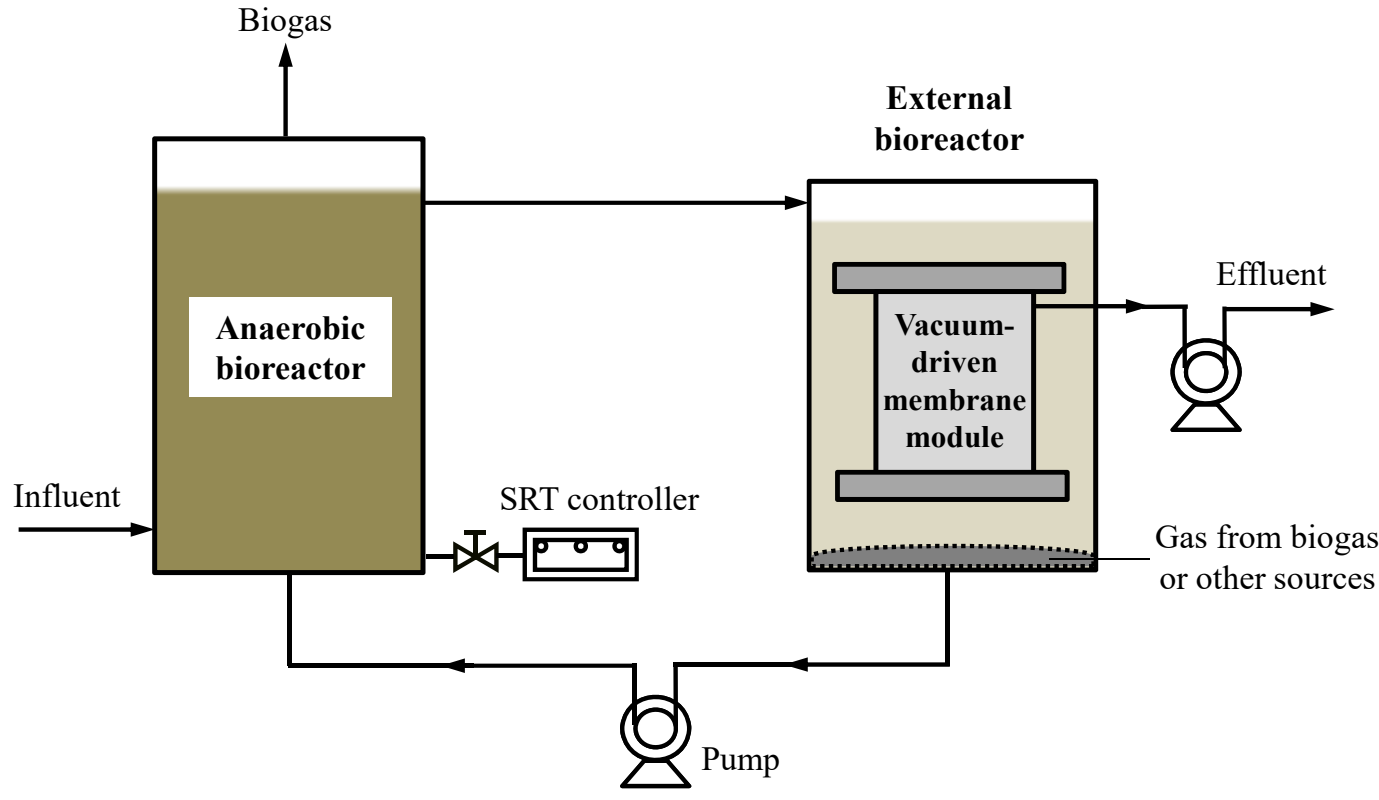

(C) SAnMBR with the membrane immersed in a separated bioreactor

Figure 25.1. Schematic of AnMBR configurations

It is well known that hydrolysis, acidogenesis, acetogenesis and methanogenesis are the four fundamental steps of anaerobic digestion. However, as a result of the difference in the rate of acidogenesis and methanogenesis, acid inhibition usually occurs and acid inhibitors such as ammonia and volatile fatty acids (VFAs) 
generated during acidogenesis can limit the methane yield and destruct the process stability, thereby leading to the insufficient anaerobic digestion (Kanai et al. 2010). Moreover, three principal anaerobic microbes, namely the hydrolyzing and fermenting microorganisms, the obligate hydrogen-producing acetogenic bacteria and the methanogenic archaea, all have extremely sensitive $\mathrm{pH}$ ranges. For example, both acetogens and acidogens need the $\mathrm{pH}$ range from 5.5 to 7.2 , while methanogens bacteria require strictly the optimal $\mathrm{pH}$ between 6.8 and 7.8 (Visvanathan and Abeynayaka 2012). Additionally, acidogenic organisms are found to grow much more rapidly compared to methanogenic bacteria. The production of acids during acidogenesis can reduce $\mathrm{pH}$ of the bioreactor, which can adversely affect methanogenic bacteria. Therefore, it would be better to separate acetogens/acidogens and methanogens into different reactors to offer desirable circumstances that allow each type of bacteria to perform at its optimal condition (Chen et al. 2008a; Zhao 2011).

Furthermore, although aerobic MBRs can produce high quality of treated effluent to meet controlled levels of organics and nutrients (nitrogen and phosphorus) and achieve almost complete nitrification, denitrification always requires the addition of an anoxic tank prior to the aeration tank with conventional recycle (Gander et al. 2000). Moreover, the concept of simultaneous nitrogen and phosphorus removal significantly depreciated the most favourable characteristics of long SRT control in aerobic MBR. Although various designs of treatment process associated with aerobic MBR have been reported through applying various combinations of anaerobic, anoxic and aerobic or multiple compartments (e.g., anoxic/anaerobic/oxic/anoxic MBR or anoxic/aerobic MBR, sequencing anoxic/anaerobic MBR, alternating of anoxic and anaerobic MBR process, anaerobic/anoxic/oxic MBR, etc.), the additional pumping, pipeline and recirculation configurations of either mixed liquor or permeate lead to higher capex, operational costs and energy consumption (Guo et al. 2010). Table 25.2 summarizes the performance comparison of conventional aerobic treatment, anaerobic treatment, aerobic MBR and AnMBR, indicating that AnMBR possesses the advantages of both anaerobic treatment and MBR technology (Lin et al. 2013).

In order to provide sufficient treatment to meet stringent effluent requirements, as well as fulfill the complete decomposition of complex organic wastes into the endproducts (e.g. methane, carbon dioxide, etc.), researchers have started investigating and developing the hybrid anaerobic systems with multistage treatment involving AnMBR process. The purposes of using the hybrid AnMBR systems are to improve effluent quality, enhance the stability of the anaerobic process, reduce waste biosolids production, reduce high energy and operating expenditure due to membrane fouling problem and maximize methane production (Yushina and Hasegawa 1994; Trzcinski and Stuckey 2009; Kanai et al. 2010; Yoo et al. 2012). Tables 25.3 and 25.4 list a number of hybrid AnMBR systems that have been employed in treating various sources of wastewater. 
Table 25.2. Comparison of the performance of conventional aerobic treatment, anaerobic treatment, aerobic MBR and AnMBR (adopted from Lin et al. 2013)

\begin{tabular}{|c|c|c|c|c|}
\hline Indicator & $\begin{array}{l}\text { Conventional Aerobic } \\
\text { Treatment }\end{array}$ & $\begin{array}{l}\text { Conventional Anaerobic } \\
\text { Treatment }\end{array}$ & Aerobic MBR & AnMBR \\
\hline Organic removal efficiency & High & High & High & High \\
\hline Effluent quality & High & Moderate to poor & Excellent & High \\
\hline Organic loading rate & Moderate & High & High to moderate & High \\
\hline sludge production & High & Low & High to moderate & Low \\
\hline Footprint & High & High to moderate & Low & Low \\
\hline Biomass retention & Low to moderate & Low & Total & Total \\
\hline Nutrient requirement & High & Low & High & Low \\
\hline Alkalinity requirement & Low & $\begin{array}{l}\text { High for certain industrial } \\
\text { stream }\end{array}$ & Low & High to moderate \\
\hline Energy requirement & High & Low & High & Low \\
\hline Temperature sensitivity & Low & Low to moderate & Low & Low to moderate \\
\hline Startup time & $2-4$ weeks & 2-4 months & $<1$ week & $<2$ weeks \\
\hline Bioenergy recovery & No & Yes & No & Yes \\
\hline Mode of treatment & Total & Essentially pretreatment & Total & Total pretreatment \\
\hline
\end{tabular}


Table 25.3. Summary of the initiatives of hybrid AnMBR systems

\begin{tabular}{|c|c|c|}
\hline Wastewater type & Purpose of research & References \\
\hline $\begin{array}{l}\text { Sewage and soybean-processing } \\
\text { wastewater }\end{array}$ & $\begin{array}{l}\text { Develop low-cost treatment processes utilizing bioreactors combined with } \\
\text { membrane units }\end{array}$ & Kimura 1991 \\
\hline $\begin{array}{l}\text { low-strength wastewater and } \\
\text { soybean-processing wastewater }\end{array}$ & Study the characteristics of highly concentrated anaerobic bacteria population & Kataoka et al. 1992 \\
\hline Municipal sewage & $\begin{array}{l}\text { Achieve high-performance separation to produce methane gas and to reclaim } \\
\text { wastewater }\end{array}$ & Kiriyama et al. 1992 \\
\hline Municipal sewage & $\begin{array}{l}\text { Establish a methane gas generation system capable of obtaining certain level of } \\
\text { conversion rate }\end{array}$ & Kiriyama et al. 1994 \\
\hline Wheat starch wastewater & $\begin{array}{l}\text { Enhance the efficiency of two-phase anaerobic degradation to treat wastewater } \\
\text { containing high strength suspended solids }\end{array}$ & Yanagi et al. 1994 \\
\hline $\begin{array}{l}\text { Soybean processing } \\
\text { wastewater }\end{array}$ & Improve the efficiency in gas production and treated water quality & $\begin{array}{l}\text { Yushina and Hasegawa } \\
1994\end{array}$ \\
\hline Piggery wastewater & $\begin{array}{l}\text { Increase the SRT of amidogens, enhance the solid separation and reduce the } \\
\text { cake resistance of membranes in an anaerobic reactor }\end{array}$ & Lee et al. 2001 \\
\hline Slaughterhouse wastewater & Overcome the VFA accumulation and mitigate acid inhibition & $\begin{array}{l}\text { Saddoud and Sayadi } \\
2007\end{array}$ \\
\hline $\begin{array}{l}\text { Municipal solid waste (Organic } \\
\text { Fraction) }\end{array}$ & Promote stability and performance of a two-stage anaerobic membrane process & $\begin{array}{l}\text { Trzcinski and Stuckey } \\
2009\end{array}$ \\
\hline Biodegradable municipal waste & Enhance the degradation of biodegradable municipal solid waste & Walker et al. 2009 \\
\hline Sand-separated dairy manure & Evaluate the potential of the proposed AnMBR to treat agricultural waste & Wong et al. 2009 \\
\hline $\begin{array}{l}\text { Distillation residue or food } \\
\text { waste }\end{array}$ & Stabilize methane fermentation & Kanai et al. 2010 \\
\hline $\begin{array}{l}\text { High strength molasses-based } \\
\text { synthetic wastewater }\end{array}$ & $\begin{array}{l}\text { Investigate the effects of the organic loading rate on VFA profile and biological } \\
\text { activity of a two-stage thermophilic AnMBR system }\end{array}$ & Wijekoon et al. 2011 \\
\hline $\begin{array}{l}\text { Municipal wastewater primary- } \\
\text { clarifier effluent }\end{array}$ & $\begin{array}{l}\text { Evaluate effluent quality, biosolids production, energy requirements and } \\
\text { production, and procedures for membrane fouling control }\end{array}$ & Yoo et al. 2012 \\
\hline
\end{tabular}


Table 25.4. Schematic diagrams of hybrid AnMBR systems

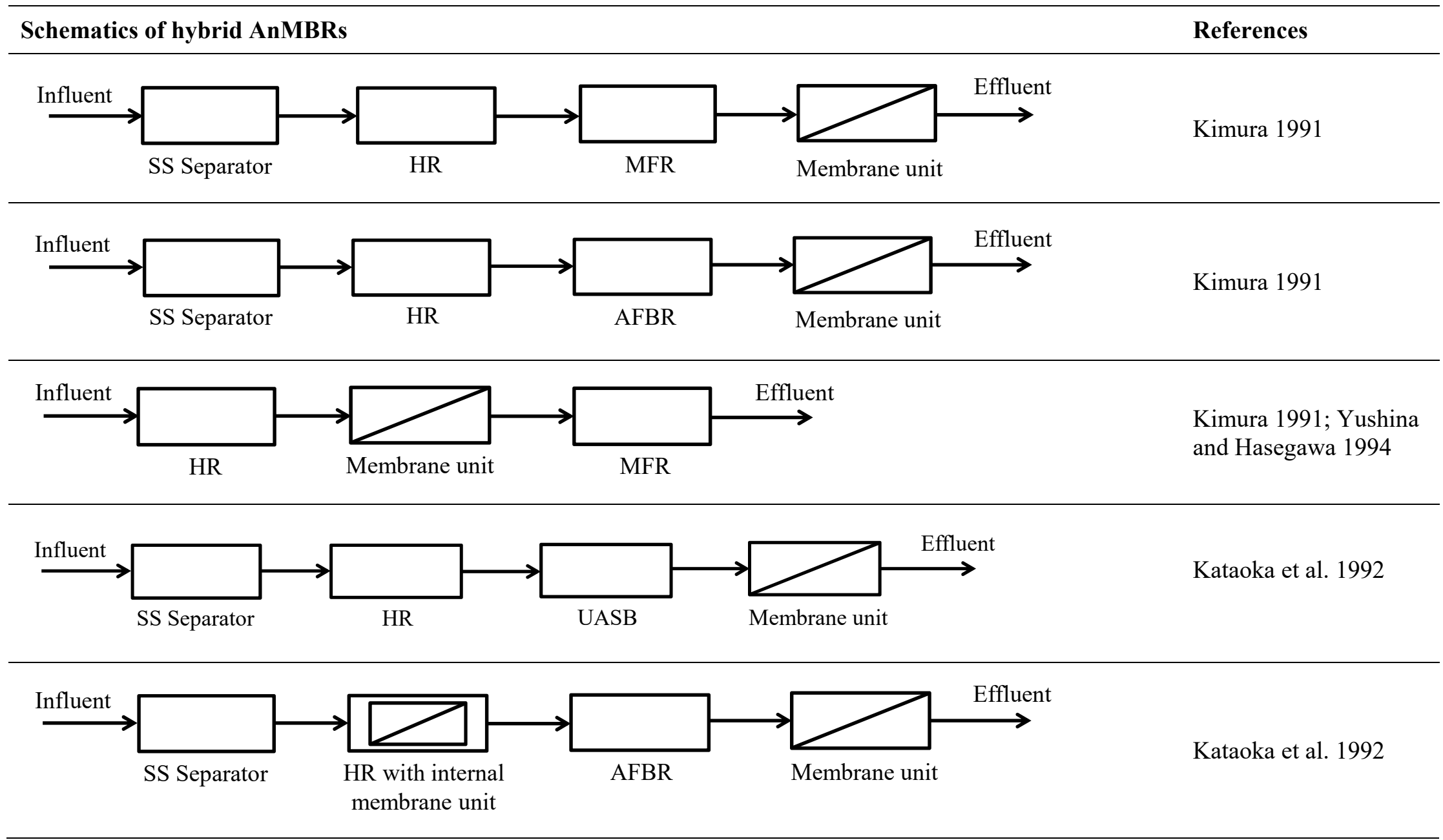




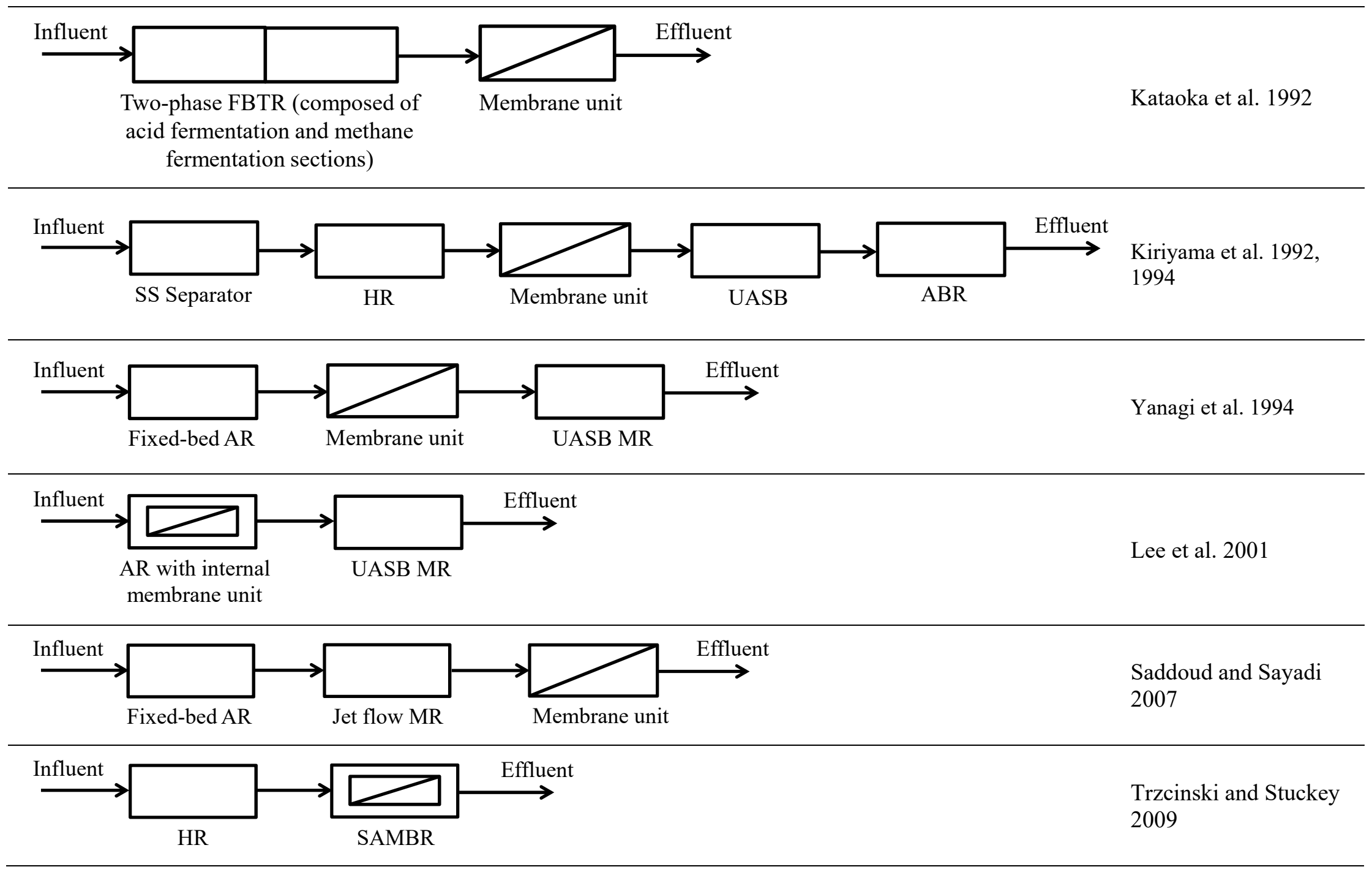




Influent

ABR: aerobic bioreactor; AF: anaerobic filters; AFBR: anaerobic fluidized-bed reactor; AFMBR: anaerobic fluidized-bed membrane bioreactor; AR: acidogenic reactor; CMAD: complete mix anaerobic digester; CMBR: coarse membrane bioreactor; FBTR: fixed-bed-type reactor; HR: hydrolyzation reactor; MFR: methane fermentation reactor; MR: methanogenic reactor; SAMBR: submerged aerobic membrane bioreactor; SAnMBR: submerged anaerobic membrane bioreactors; SS: suspended solids; UASB: upflow anaerobic sludge blanket. 


\subsection{The Current Status of AnMBRs in Wastewater Treatment}

\subsubsection{Municipal Wastewater Treatment}

The anaerobic treatment processes are known to have the inherent advantages over the aerobic counterparts, such as sludge minimization and energy savings. However, anaerobic processes have been historically less employed for municipal/domestic wastewater treatment because of its low organic strength and high-suspended solids concentration (Liao et al. 2006; Lew et al. 2009). Furthermore, there have other two reasons causing the less popularity of anaerobic applications. Firstly, it is rare that anaerobic effluent can meet the discharge requirements, as anaerobic metabolism exist the kinetic limitations especially when the treatment processes experience the low temperatures. At low temperatures, the hydrolysis of suspended solids and colloidal fractions is the rate-limiting step, impeding anaerobic digestion of municipal wastewater. Secondly, it is difficult to retain the slow-growing anaerobic microbes with the short hydraulic retention time in association with low strength wastewater treatment. Therefore biomass concentrations are difficult to maintain, and can be mostly washed out from reactors (Uemura and Harada 2000; Lettinga et al. 2001; Martinez-Sosa et al. 2012; Lin et al. 2013).

However, the degradation efficiency can be enhanced by increasing the suspended solids retention time in an anaerobic reactor. Hence, AnMBR has been found extraordinarily attractive because it can maintain very high solids concentration as no particulates could be expelled from the membrane system (Lew et al. 2009). This means that the complete hydrolysis and decomposition of the retained particulate organics can be eventually accomplished due to the long SRT. Moreover, the anaerobic bacteria with relatively low growth rates can be allowed to fully grow without being washed out from the reactor. Additionally, comparing with aerobic MBRs, AnMBR can actually bring about a green approach to renewable sources of energy (methane production), lower sludge production and no extra energy consumption associated with aeration.

During municipal wastewater treatment, AnMBR is usually fed with primary treated effluent to protect membrane from the damage due to large particles and to maximize the longevity of membrane life. Thus, effective pretreatment such as screening and settling should be implemented to ensure the efficacy of AnMBR. Although the majority of AnMBR research in municipal wastewater treatment has been remained restricted to the external module (Lin et al. 2011), this configuration has its own inherent weaknesses as mentioned before, and the submerged anaerobic membrane bioreactors have gained a great popularity among the research and industrial divisions in recent years. So far, researchers have been looking into the AnMBRs based on three areas (Lin et al. 2013): 1) the removal of common contaminants such as COD and total suspended solids (TSS); 2) the removal of nutrients such as total nitrogen (TN) and total phosphorus (TP); and 3) the removal of trace contaminants such as endocrine disrupting chemicals (EDCs) and pharmaceutically active compounds (PhACs). 
According to the review of Lin et al. (2013), AnMBR systems can achieve more than $85 \%$ COD and $99 \%$ TSS removal at certain operational conditions, while Elmitwalli et al. (2001) have reported that the anaerobic biodegradation of domestic wastewater tended to be relatively low in terms of COD removal (71-74\%). Hence, it is suggested to implement aerobic post-treatment to further enhance COD and nutrient removal (Chan et al. 2009). Nevertheless, the high removal efficiency of nutrients such as TN and TP is not expected in the AnMBR systems because the removal of TN and TP requires the anoxic or aerobic zone. As a result, it can be an advantage if the effluent is to be utilized directly to fulfill the irrigation or agricultural purpose. Nevertheless, in most cases, a further nutrient removal process is needed if the effluent is to be reused. Available nutrient removal technologies include conventional biological measures, partial nitritation/nitrification, forward osmosis (FO) processes, and physical/chemical nutrient removal processes (Lin et al. 2013).

With the growing environmental health concerns of the effects of the micropollutants, research has been focused on investigating the ways of removing micropollutants from the treated and untreated municipal wastewater. The anaerobic biodegradation of these trace contaminants was proved to be less effective, but the tactics of prolonging HRT ( $>30 \mathrm{~d}$ ) and the adoption of bioaugmentation can serve as an effective countermeasure to enhance the removal efficiency, particularly for PhACs (Kujawa-Roeleveld 2008; Ifelebuegu 2011). Saravanane and Sundararaman (2009) applied bioargumentation to a SAnMBR process in treating highconcentration antibiotic wastewater, and the treated effluent met the requirement for discharge with consistent quality. Saddoud et al. (2009) stated that if the domestic wastewater composition polluted by the toxic compounds originating from the industrial activities, the AnMBR process could be inefficient and likely to cause considerable variations in the biogas production rates and the methane levels present in the biogas. They also mentioned that the exposure to toxicity induced by industrial chemicals in the domestic influent could actually harm the biomass in reactors, which possibly led to the upset or even failure of the treatment system.

In terms of the economic attractiveness of AnMBR, many efforts have been made to observe whether the transition from conventional MBRs to anaerobic MBRs is an economically viable choice. The results show that under similar conditions, conventional ones and AnMBRs are able to produce similar soluble COD removal rates (Baek and Pagilla 2006). However, AnMBR can save all costs for aeration, which significantly elevates its economic efficiency. Nevertheless, operational temperature is a vital factor to determine the cost-effectiveness of AnMBRs, and this is due to the fact that the heating of anaerobic reactors requires heavy energy and capital expenditure. With respect to domestic wastewater treatment with a low organic content, operating under ambient temperature is favored because the low methane production cannot cover the heating requirements (Martinez-Sosa et al. 2011; Skouteris et al. 2012). Therefore, AnMBRs are usually suggested to operate under mesophilic $\left(30-37{ }^{\circ} \mathrm{C}\right)$ or thermophilic $\left(50-55^{\circ} \mathrm{C}\right)$ temperature conditions so as to ensure the optimal biological activity, and maximize the economic efficiency (Du 
Preez et al. 2005; McKeown et al. 2011). On the other hand, Martinez-Sosa et al. (2011) has demonstrated an AnMBR for municipal wastewater treatment under psychrophilic temperature condition $\left(20-28{ }^{\circ} \mathrm{C}\right)$. The results have proven the feasibility of AnMBR in low temperature region. Although aggravated membrane fouling was observed at psychrophilic temperatures that probably linked to an accumulation of TSS and soluble COD in the reactor, the AnMBR still had COD removal rate marked nearly $90 \%$ with effluent $\mathrm{COD}$ and $\mathrm{BOD}_{5}$ lower than 80 and 25 $\mathrm{mg} / \mathrm{L}$, respectively.

\subsubsection{Industrial Wastewater Treatment}

The industrial sectors have been facing with the ever-stringent requirements on the effluent quality. The challenges are even more intensified when the significant amounts of discharged industrial wastewaters with extreme conditions are likely to occur more often in the future. The reduction in water consumption, water reuse and resource recovery are the three main goals that the cleaner industry has to achieve. Industrial wastewater is typically characterized by its high organic strength and extreme physical-chemical conditions in terms of $\mathrm{pH}$, temperature and salinity. The presence of certain synthetic and natural toxic substances can be also found frequent in industrial wastewaters, and it could adversely influence the biological treatment processes. Each year, a large quantity of industrial wastewater is generated as a result of the ever-rapid industrialization, including effluents from food processing, pulp and paper, textile, chemical, pharmaceutical, petroleum, tannery, and manufacturing industries. To treat these wastewaters in a sustainable and efficient manner, the applications of AnMBR are advocated because of its intrinsic advantages. At present, AnMBRs have been widely used in food industrial wastewater treatment with both pilot- and full-scale applications. By contrast, the treatment of non-food processing effluents by AnMBRs applications is restricted mostly at lab- and pilot-scale (Liao et al. 2006; Dereli et al. 2012; Guo and Ngo 2012; Lin et al. 2013).

Wastewater from food industry is generally biodegradable and non-toxic, and it contains a high concentration of organics (1000-85000 COD mg/L) and suspended solids (50-17000 mg/L). In most cases, anaerobic digestion has been considered as a suitable method treating such wastewater. Since approximately $76 \%$ of all anaerobic reactor installations are in the food related industries, AnMBR applications have gained the most popularity in food processing wastewater treatment compared to other kinds of industrial wastewaters. Many AnMBR systems have been adopted in treating effluents from field crop processing (wheat starch, gluten and soybean), the dairy industry (whey), and the beverage industry (winery and distillery). Regarding the treatment performance of AnMBR, more than 90\% COD usually could be removed when the applied organic loading rates (OLR) were between 2 and 15 $\mathrm{kgCOD} / \mathrm{m}^{3} \cdot \mathrm{d}$. This treatable OLR range was lower than the existing high-rate anaerobic reactors (HRARs) with $5-40 \mathrm{kgCOD} / \mathrm{m}^{3} \cdot \mathrm{d}$, but was higher than the traditional CSTR digesters. Most AnMBR studies associated with food processing wastewater have used CSTR with external pressure-driven cross-flow membrane unit (Liao et al 2006; Lin et al. 2012; Lin et al. 2013). There are also some cases that 
hybrid AnMBR systems were utilized in the studies to facilitate the biomass growth and enhance treatment efficiency (Tables 25.3 and 25.4).

Wastewaters from non-food industries are generated from a broad variety of industrial plants and manufacturing processes, and the features of these industrial wastewaters are sector specific. However, in general, they have similarities in terms of high organic strengths and embrace natural and synthetic chemicals, which can be hardly bio-degradable or non-degradable through anaerobic and/or aerobic processes. Conventionally, industrial wastewater treatment usually has to utilize various treatment processes, such as physical treatment (screening, sedimentation, filtration, skimming, water cooling and heating), chemical treatment (coagulation and flocculation, precipitation, chemical immobilization), and biological treatment (activated sludge processes, bioargumentation, constructed wetlands and membrane bioreactors); no single type of treatment can accomplish the whole task (Liao et al. 2006, Guo and Ngo 2012).

There is a significant concern to the biological treatment of such wastewater as the presented toxicity can harm microorganisms, especially anaerobic ones. Anaerobic systems are complex and nonflexible, and have low capability of tolerating the toxins or inhibitory substances presented in substantial concentrations, which are the primary contributors to the upset or failure of the anaerobic digestion processes (Liao et al. 2006; Chen et al. 2008a). In particular, methanogenic microbes have higher possibility of being easily inhibited by toxic substances, resulting in the problems such as low methane yield and process instability (de Lemos Chernicharo 2007). However, AnMBRs have an obvious advantage over the conventional anaerobic systems because complete biomass retention can still be achieved even though inhibitors upset the system. As substances with high toxicity levels can hardly cause cell death, the treatment process may be temporarily impaired and eventually be recovered again (Liao et al. 2006). Moreover, the adverse impact can also be minimized if some feasible measures can be provided in place. The appropriate precautions include designing measures (e.g. prolonging the SRTs) and control methods (e.g. dilution below the toxicity level, pretreatment prior to AnMBR applications to remove toxic compounds, or acclimation of biomass by gradual increase of toxic levels) (Speece 1996; De Lemos Chernicharo 2007; Liao et al. 2010).

Some cases where AnMBRs were used in the treatment of such non-food processing wastewater are given in details:

Pulp and Paper Industry Wastewater. Paper and pulp industry wastes contain high COD concentrations because the produced pulp is equivalent to only $40-45 \%$ of the original weight of the wood (Ali and Sreekrishnan, 2001). Furthermore, high temperature usually can be observed in the effluent, which is typically around $35^{\circ} \mathrm{C}$. These two main characteristics make anaerobic digestion a promising treatment technique. According to Kleerebezem and Macarie (2003), anaerobic treatment of such wastewater has gained more and more popularity and roughly $9 \%$ of all anaerobic installations are for the pulp and paper industry. The 
number of the reported studies about AnMBRs' ability in treating pulp and paper industry wastewater has increased rapidly. Overall, more than $90 \%$ BOD could be eliminated in most cases, while the unsatisfactory absorbable organic halogens (AOX) removal $(61 \%)$ was detrimental, implying the performance instability of AnMBRs. The system instability could be explained by the process inhibition, and the most common inhibitors to AnMBRs for treating pulp and paper industry wastewaters are sulfide, tannins acids, long chain fatty acids (LCFA) and halogenated compounds (Kimura 1991; Minami 1994; Okamura 1994; Ali and Sreekrishnan, 2001; Liao et al. 2006).

Evaporator condensate (EC) is one kind of the important wastewaters produced from the pulp and paper industry, and is of a major concern of the researchers, as it can be readily converted to methane during treatment (Xie et al. 2010). EC is typically characterized by its high soluble COD concentration (10-42 $\mathrm{g} / \mathrm{L}$ due to methanol), high temperature, low suspended solids $(<3 \mathrm{mg} / \mathrm{L})$, and the presence of inhibitory substances including total reduced sulfur (TRS) compounds and terpene oils (Minami et al. 1991; Minami 1994). Thus, the pretreatment of condensate to remove the above mentioned toxic materials are highly recommended to maintain the system stability, and enhance the EC treatment performance. Minami (1994) operated a pilot-scale AnMBR to treat EC, and the condensate was pretreated through microfiltration and biogas stripping. $\mathrm{pH}$ was adjusted to neutral to ensure that the pretreated effluent was amenable to treatment in a thermophilic attached growth ultrafiltration AnMBR. More than 93\% BOD removal efficiency was achieved with OLR of $35.5 \mathrm{kgCOD} / \mathrm{m}^{3} \cdot \mathrm{d}$, which was more than doubled when compared with 15 $\mathrm{kgCOD} / \mathrm{m}^{3} \cdot \mathrm{d}$ OLR without the membrane.

Operating AnMBR under thermophilic temperatures may be favorable for EC treatment and reuse, because precooling and post-heating used in the mesophilic treatment can be avoided (Lin et al. 2012; Lin et al. 2013). Lin et al. (2009) have done a comparable study on two parallel SAnMBRs (mesophilic SAnMBR operated at 37 ${ }^{\circ} \mathrm{C}$ and thermophilic SAnMBR operated at $55^{\circ} \mathrm{C}$ ) treating kraft EC at a feed COD of $10,000 \mathrm{mg} / \mathrm{L}$. Similar results in terms of COD removal (97-99\%) and substantial methane production were reported in both SAnMBRs. The results showed that both mesophilic and thermophilic SAnMBRs have the potential of being promising processes for the treatment of kraft EC when considering the aspects of COD removal and biogas production. Nevertheless, the challenges of much-worsening membrane fouling were observed in thermophilic SAnMBR due to the fact that high temperature and relatively lower OLR could accelerate soluble microbial products (SMP) and disrupt sludge flocs. In addition, as sludge cake layers in the thermophilic SAnMBR were more compact and less porous, the filtration resistance in the thermophilic SAnMBR was about 5-10 times higher than that of the mesophilic SAnMBR when operated under similar hydrodynamic conditions. With regard to economic attractiveness of AnMBRs in treating paper and pulp industry wastewaters, it was concluded that the total capital cost using AnMBR to treat kraft mill effluent was remarkably lower than that of aerobic treatment, and only a bit higher than that of 
high rate anaerobic reactors (HRARs) such as UASB, whereas the effluent quality of AnMBR was the best (Kimura 1991; Minami 1994; Okamura 1994).

Textile Industrial Wastewater. The wastewaters from the textile industry mainly originate from the washing or scouring, bleaching of natural fibers and the dyeing and finishing steps, and have great chemical complexity (Vandevivire et al. 1998, Chen et al. 2008a). Several lab-scale studies have demonstrated that methanogenic microorganisms could be easily inhibited by textile effluent due to the potential inhibitors such as dye, heavy metals and surfactants (Athanasopoulos 1992; Feitkenhauer 2004; Lee and Pavlostathis 2004). Hence, the potential of anaerobic treatment of such wastewater is considered low and it was found that only $1 \%$ of all industrial scale anaerobic installations are for the textile industry (Kleerebezem and Macarie 2003). There are some cases in the literature investigating the efficiency of the AnMBR technology for the treatment of textile industrial wastewater. Hogetsu et al. (1992) reported the anaerobic treatment of wool scouring wastewater using a fixed-bed anaerobic reactor combined with UF filter achieved good total oxygen demand (TOD), wool grease and SS removal efficiency of more than 89, 98 and $100 \%$, respectively at the TOO loading rates of up to $20 \mathrm{~kg} / \mathrm{m}^{3} \cdot \mathrm{d}$. The recirculation of rejected liquid from the UF filter contributed to higher concentration of biomass (about two times than the process without recirculation) and 33\% of organic solids decomposition.

Spagni et al. (2012) investigated Azo dye decolourisation of textile wastewater in a SAnMBR, and the reactive orange 16 was used as a model of an Azo dye. The results demonstrated that very high decolourisation $(>99 \%)$ could be achieved by SAMBRs. Although decolourisation was not significantly influenced by the Azo dye concentrations up to $3.2 \mathrm{~g} / \mathrm{L}$, methane production was greatly inhibited (up to $80-85 \%$ ) because of the accumulation of volatile fatty acids in the treatment system, suggesting methanogens seem to be the most sensitive microbial populations of the anaerobic ecological community. In another study, Baêta et al. (2012) conducted experiments to evaluate the performance of two SAnMBRs with and without the presence of powdered activated carbon (PAC) for genuine textile wastewater treatment. Both SAnMBRs were operated at $35^{\circ} \mathrm{C}$ with an HRT of $24 \mathrm{~h}$ and the textile effluent was diluted (1:10) with nutrient solution containing yeast extract as the source of the redox mediation riboflavin. Although both SAMBRs exhibited an excellent performance, the results indicated that the addition of PAC into SAnMBR could enhance reactor stability and improve the removal efficiency of COD and color (90 and $94 \%$ respectively), while 79 and $86 \%$ removal was obtained in the SAnMBR without PAC addition. In addition, the mean values of turbidity and VFA were $8 \mathrm{NTU}$ and $8 \mathrm{mg} / \mathrm{L}$ for SAnMBR with PAC and $14 \mathrm{NTU}$ and $26 \mathrm{mg} / \mathrm{L}$ for SAnMBR without PAC, suggesting that the presence of PAC inside SAnMBR led to the production of higher quality anaerobic effluent.

Petroleum Industry Wastewater. Petrochemical waste is generally characterized by its high BOD and COD concentrations, as well as high amounts of oil and total solids. Anaerobic digestion of high strength petrochemical refinery 
wastewater could also be a promising option. However, according to the review of Lin et al. (2013) on AnMBR's applications in industrial wastewater treatment, the cases of AnMBRs treating petroleum industrial effluents have only been reported twice in the last 6 years and neither of them was developed in an industrial scale (Van Zyl et al. 2008; Niekerk et al. 2009). The lab-scale SAnMBR was developed by Van Zyl et al. (2008) to treat high strength (18 gCOD/L) petrochemical wastewater from Sasol's coal to fuel synthesis process consisting mostly of $\mathrm{C} 2$ to $\mathrm{C} 6$ short chain fatty acids with a low $\mathrm{pH}$. With OLR up to $25 \mathrm{kgCOD} / \mathrm{m}^{3}$ reactor volume per day and HRT of $17 \mathrm{~h}, 98 \%$ of the COD was converted to methane (with effluent COD $<500$ $\mathrm{mgCOD} / \mathrm{L}$ and ammonia $<50 \mathrm{mg} / \mathrm{L}$ and no particulates $>0.45 \mu \mathrm{m}$ ) and the submerged flat panel UF membranes could provide $100 \%$ solids-liquid separation. Besides, more than $30 \mathrm{~g} / \mathrm{L}$ TSS in mixed liquor could be maintained without deterioration of membrane fluxes. On the other hand, the preliminary pilot-scale investigations undertaken by Niekerk et al. (2009) proved that anaerobic granules did not readily form with Fisher-Tropsch Reaction Water (FTRW) and there were effluent quality concerns with the system. Regarding process inhibition, the prolonged acclimation could eventually biodegrade acids, alcohols and esters into methane, whereas anaerobic digestion of petrochemical wastes would not contribute to energy savings over aerobic processes, and however the produced biogas could be used as a renewable source of energy (Chou et al. 1978).

Pharmaceutical Wastewater. The proper treatment of pharmaceutical wastewaters was often neglected worldwide and an estimation of half of the pharmaceutical wastewater produced all over the world is discarded (Lang 2006; Enick and Moore 2007). Presently, research and development, the conversion of organic and natural substances into bulk pharmaceutical substances or ingredients through fermentation, extraction, and/or chemical synthesis, as well as the formulation and assembly of the final pharmaceutical product all generate pharmaceutical wastewaters (Oktem et al. 2007). The disposal of pharmaceutical wastewater without appropriate treatment has led to an urgent water pollution problem as approximately $80-100$ pharmaceuticals and their metabolites have been found in both effluent and surface waters in a number of countries (Ankley et al. 2005; Fent et al. 2006; Owen et al. 2007).

With the advantages in dealing with high strength wastewaters, anaerobic processes such as CSTR reactors, UASB reactors and anaerobic filters, have been attempted as an effective means to decrease the organic content of chemical synthesis-based pharmaceutical wastewater. The case of applying only AnMBR to treat pharmaceutical wastewater is very limited because anaerobic microbes alone cannot be able to biodegrade refractory contents in the wastewater. Moreover, owing to the different rates of acidogenesis and methanogenesis, and the subsequent occurrence of acid inhibition using single-stage anaerobic digester, hybrid anaerobic systems have to be introduced to reduce the competitions between different microorganisms and mitigate acid inhibition when treating pharmaceutical wastewater. Therefore, to meet the direct discharge requirement, the anaerobic unit combined with a subsequential aerobic process is often applied (Oz et al. 2002; Lin et 
al. 2013). For example, Chen et al. (2008b) have applied a pilot-scale integrated system, which consists of a two-phase anaerobic digestion and an aerobic MBR unit, for treating chemical synthesis-based pharmaceutical wastewater $(5789-58792 \mathrm{mg} / \mathrm{L}$ COD and 4.3-7.2 $\mathrm{pH}$ ) from a local pharmacy company. The TPAD system comprised a CSTR and an UASB-anaerobic filter, working as the acidogenic and methanogenic phases, respectively. With HRTs of 12,55 and $5 \mathrm{~h}$, the integrated system could remove almost all the COD, and the effluent from MBR had COD around $40 \mathrm{mg} / \mathrm{L}$ ( $>$ $99 \%$ removal) and $\mathrm{pH}$ of $6.8-7.6$, suggesting that the MBR effluent is qualified to be discharged into natural waters directly.

\subsection{Opportunities for AnMBR Processes and Energy Recovery}

\subsubsection{Biogas Production and Waste Minimization}

Methane fermentation is a complex biological process, which mainly occurs in four steps: hydrolysis, acidogenesis, acetogenesis and methanogenesis. Hydrolysis acts as the first attack on the insoluble organic material and higher molecular mass compounds including polysaccharides, fat, protein, etc. The enzyme-mediated transformation is accomplished in this stage to convert such polymers into compounds suitable for the use as the source of energy and cell carbon such as monosaccharides, amino acids, acetate and varying amounts of VFAs. Acetate and hydrogen could also be produced as an ending product in the first stage, and they can be utilized by methanogens directly. In the second step, the biological process of acidogenesis takes place, and acidogenic bacteria further breaks down the simple monomers into VFAs, along with ammonia, carbon dioxide and hydrogen sulphide as well as other byproducts (Yadvika et al. 2004; Weiland 2010; Wikipedia 2013).

In the step of acetogenesis, acetogens further digest the simple molecules created in the acidogenesis stage, and VFAs are converted into largely acetic acid as well as carbon dioxide and hydrogen by acetogenic bacteria. It is worth mentioning that the accumulation of hydrogen can inhibit the metabolism of the acetogenic microbes. Therefore, the maintenance of extremely low partial pressure of hydrogen is required for the well-being of the acetogenic and hydrogen-producing bacteria (Weiland 2010). Methanogenesis is the terminal step that contributes to the most methane production. The methanogenic bacteria usually use up intermediate products of the preceding stages including acetic acids, hydrogen and carbon dioxide, and convert them into methane, carbon dioxide and water. In this final phase, the availability of hydrogen is believed to be a limiting factor for hydrogenotrophic methanogens due to the fact that addition of the hydrogen-producing bacteria can increase the biogas yield (Bagi et al. 2007). As the final product of anaerobic digestion, biogas is mainly composed of methane and carbon dioxide, which can be considered as an alternative source of renewable energy.

A balanced methane fermentation process requires the individual degradation

phases to be carried out by distinct consortia of bacteria, and these microorganisms 
are supposed to behavior in a syntrophic manner to perform efficiently (Angelidaki et al. 1993). For such a complex anaerobic microbial community, biogas formation depends on the activities of various groups of microorganisms of the anaerobic digestion (Gao et al. 2011). The detailed description of different types of microbes is shown in Table 25.5.

Table 25.5. Description of anaerobic microorganisms in each stage

\begin{tabular}{ll}
\hline $\begin{array}{l}\text { Anaerobic } \\
\text { Microorganisms }\end{array}$ & Examples \\
\hline $\begin{array}{l}\text { Hydrolytic and fermenting } \\
\text { microorganisms }\end{array}$ & $\begin{array}{l}\text { Strict anaerobes such as Bactericides, Clostridia and } \\
\text { Bifidobacteria, and facultative bacteria such as } \\
\text { Streptococci and Enterobacteriaceae }\end{array}$ \\
$\begin{array}{l}\text { Obligate hydrogen- } \\
\text { producing acetogenic } \\
\text { bacteria }\end{array}$ & $\begin{array}{l}\text { Homoacetogenic bacteria such as acetobacterium woodii } \\
\text { and Clostridium aceticum }\end{array}$ \\
Methanogenic bacteria & $\begin{array}{l}\text { Two types of strict anaerobes: } \\
\text { i) Very few species degrade acetate into methane and } \\
\text { carbon dioxide such as Methanosarcina barkeri, } \\
\text { Methanococcus mazei and Methanothrix soehngenii }\end{array}$ \\
& ii) Most species use hydrogen to form methane. \\
\hline
\end{tabular}

Wastewater has been regarded as a valuable energy source with the development of anaerobic digestion technology. The production of biogas offers significant advantages, including: 1) producing less biomass sludge compared to aerobic treatment technologies; 2) successfully treating wet wastes of $<40 \%$ dry matter; 3) more effectively removing pathogens, especially for multi-stage digesters; 4) minimizing odor emissions as $99 \%$ of volatile compounds are oxidatively decomposed upon combustion; 5) reducing the amount of biodegradable waste entering landfill; 6) The slurry produced being an improved fertilizer; and 7) producing a source of carbon neutral energy in the form of biogas. Additionally, the utilization of biogas can benefit the reduction of fossil fuel usage and greenhouse gas emissions (Ward et al 2008; Weiland 2010).

AnMBR, which incorporates anaerobic digestion with membrane separation technology, can play a key role in transforming conventional processes to a more stable and more efficient future green process as well as improve the sustainability of this energy-intensive industry. It is capable of producing methane continuously through utilizing a large fraction of organics in the wastewater. Van Zyl et al. (2008) mentioned that AnMBR can convert approximately 98\% of the influent COD into biogas. Lin et al. (2013) reported that although methane yield in AnMBR was generally less than the theoretical yield $\left(0.382 \mathrm{~L} \mathrm{CH} / \mathrm{gCOD}\right.$ removed at $\left.25{ }^{\circ} \mathrm{C}\right)$ because of high methane solubility, the value was quite considerable, ranging from

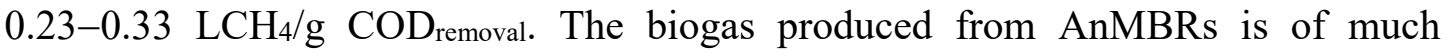
greater fuel quality and in some cases, having a composition of $80-90 \%$ methane 
content, and this value compares favorably with the $60-65 \%$ obtained from the conventional anaerobic digesters. The higher methane content is attributed to the shorter HRTs by applying membrane for sludge separation in AnMBR (Demirel et al. 2010; Skouteris et al. 2012).

Saddoud et al. (2007) have studied a two-phase anaerobic digestion process consisting of a stirred acidogenic reactor followed by a stirred methanogenic reactor, which was coupled with membrane filtration for cheese whey effluent treatment. Average removals of COD, $\mathrm{BOD}_{5}$ and TSS in this system were $98.5,99$ and $100 \%$, respectively. Combining the membrane system with the methanogenic reactor enhanced the daily biogas production, which exceeded 10 times the reactor volume at HRT of 4 days with the average rate of $0.3 \mathrm{~L} \mathrm{CH}_{4} / \mathrm{gCOD}$ removed. The biogas production increased steadily with the increase in OLR and the biogas methane content was greater than $70 \%$. Xie et al. (2010) investigated the feasibility of employing a SAnMBR for kraft EC treatment at $37 \pm 1{ }^{\circ} \mathrm{C}$ over a 9 -month period. The performance of the lab-scale SAnMBR was examined in terms of COD removal and biogas production (chemical composition and rate). The SAnMBR achieved an overall soluble COD removal efficiency of 93-99\% with a feed COD concentration varying from $2600-10,000 \mathrm{mg} / \mathrm{L}$. The effluent was colorless, had a very low soluble COD (50-200 mg/L) and zero solids concentration. Under tested OLRs of 1-24 kg $\mathrm{COD} / \mathrm{m}^{3} \cdot$ day, the methane production rates ranged from $0.25-0.40 \mathrm{~L} \mathrm{CH}_{4} / \mathrm{gCOD}$ removed with the mean value of $0.35 \pm 0.05 \mathrm{~L} \mathrm{CH}_{4} / \mathrm{gCOD}$ removed, which were very close to the theoretical yield of methane $\left(0.397 \mathrm{~L} \mathrm{CH}_{4} / \mathrm{g}\right.$ COD removed at $\left.37{ }^{\circ} \mathrm{C}\right)$. Moreover, an average of $80-90 \%$ methane was found in the biogas, indicating higher methane content as compared to conventional anaerobic digestion. In addition, the effective bubbling of recycled biogas could contribute to in-situ membrane cleaning, thereby mitigating membrane fouling. The membrane critical flux increased and the membrane fouling rate decreased with an increase in the biogas sparging rate.

Lin et al. (2011) operated a lab-scale SAnMBR for municipal secondary wastewater treatment. The methane yield rate of this study was $0.26 \mathrm{~L} \mathrm{CH}_{4} / \mathrm{gCOD}$ removed with COD removal efficiency of approximately $90 \%$. The high content of methane (75-85\%) in the biogas was observed with 5-8\% carbon dioxide and 5-15\% nitrogen, which demonstrated that municipal wastewater is a great food source for energy recovery through the metabolism of anaerobic methanogens. A pilot-scale SAnMBR for municipal wastewater treatment under mesophilic and psychrophilic temperature conditions was operated by Martinez-Sosa et al. (2011) to measure biogas production and biogas composition. The average methane yields of 0.27 and $0.23 \mathrm{~L} \mathrm{CH} / \mathrm{gCOD}$ removed were obtained under mesophilic $\left(35^{\circ} \mathrm{C}\right)$ and psychrophilic $\left(20^{\circ} \mathrm{C}\right)$ conditions, which represent only $77 \%$ and $70 \%$ of the maximal theoretical value respectively. This was because not all organic wastes were properly degraded, but physically retained by the membrane in the reactor, and the real amount of degraded organics were supposed to be lower than that was used to calculate the methane yield. Besides, an accumulation of particulate organics in the reactor was observed when the temperature reduced from 28 to $20^{\circ} \mathrm{C}$, which might lead to the 
decrease of methane yield under psychrophilic condition (Martinez-Sosa et al. 2011; Martinez-Sosa et al. 2012).

Apart from excellent effluent quality and energy production, the added benefit of sludge minimization is another highlight of the AnMBR applications. The low biosolids production is due to the fact that AnMBRs can permit a long SRT while maintain a short HRT. Using AnMBR, almost all the particulate and colloidal organics are supposed to be captured, and completely hydrolyzed and decomposed under the condition of the long SRT. Hence, the low sludge yield rate obtained during the treatment can contribute to a significantly reduced sludge handling and disposal cost. Lin et al. (2011) mentioned that the sludge yield of anaerobic digestion was normally less than that of aerobic processes. The SAnMBR they operated showed sludge yield coefficient of $0.032 \mathrm{~kg}$ MLSS $/ \mathrm{kgCOD}$ removed, corresponding well with the value $(0.0378 \mathrm{~kg}$ MLVSS $/ \mathrm{kgCOD}$ removal; MLVSS: mixed liquor volatile suspended solids) of the external AnMBR (Anderson et al. 1996). Yoo et al. (2012) also reported a low biosolids production when using a lab-scale staged anaerobic fluidized membrane bioreactor (SAF-MBR) system to treat a municipal wastewater primary-clarifier effluent. With the higher membrane flux of $9 \mathrm{~L} / \mathrm{m}^{2} \cdot \mathrm{h}$ and lower total system HRT of $2.3 \mathrm{~h}$, total COD and $\mathrm{BOD}_{5}$ removals of the two-stage system were $84 \%$ and $92 \%$ respectively. Furthermore, the secondary sludge production $(0.031 \mathrm{~g}$ $\mathrm{VSS} / \mathrm{gCOD}$ or $0.049 \mathrm{~g} \mathrm{VSS} / \mathrm{gBOD}_{5}$ removed) was far less than the typical $0.42 \mathrm{~g}$ $\mathrm{VSS} / \mathrm{gBOD}$ reported for aerobic secondary wastewater treatment.

\subsubsection{Operational Parameter Affecting Biogas Production}

There are several important operating parameters, which could influence the performance of AnMBR in terms of biogas yield, such as temperature, $\mathrm{pH}$, HRT and SRT.

Temperature. Temperature is a vital parameter that has profound influences on the biogas production. Basically, anaerobic fermentation can be carried out in three different temperature ranges: psychrophilic $\left(<30^{\circ} \mathrm{C}\right)$, mesophilic $\left(30-40{ }^{\circ} \mathrm{C}\right)$ and thermophilic $\left(50-60^{\circ} \mathrm{C}\right)$. When the methane fermentation process is experienced under low-temperature conditions, the hydrolysis and solubilization of complex organic matter into soluble substrates will become a rate-limiting step (Lettinga et al. 2001; Lew et al. 2003; Lew et al. 2009). Psychrophilic temperature can also negatively affect methanogenic activities and slow down the methanogenic process. Besides, the loss of methane is another issue because the solubility of methane is much more enhanced when experiencing low temperatures (Souza et al. 2010).

Theoretically, an increase in operational temperature can accelerate the metabolic rate of the slow-growing anaerobic microorganisms, and benefit the maximum specific growth and substrate utilization rates, and thus increase biogas production. In particular, the growth rate of methanogenic bacteria is higher under thermophilic conditions, making the process faster and more efficient. Hence, a wellfunctioning thermophilic digester always can be loaded to a higher degree or operated 
at a lower HRT than at mesophilic conditions. For certain industrial wastewater streams, operating under thermophilic temperatures is of great interest because this kind of wastewater is usually high temperature, and precooling/post-heating used in the mesophilic treatment for the subsequent reclamation of treated effluent could be avoided (Chen and Hashimoto, 1980; Yadvika et al. 2004; Chen et al. 2008a; Weiland 2010; Lin et al. 2013). However, higher temperatures do not necessarily always contribute to high biogas yields. In fact, the methane fermentation process can achieve the best results only when the optimal temperature range is adopted in the operation. Temperature higher than the optimal can result in an irreversible damage to proteins and other cellular components, and this will in turn lead to the performance loss of AnMBRs in terms of biogas production issue (Luostarinen 2005; Zhao 2011). Additionally, the temperature of thermophilic process is believed to cause ammonia toxicity problem, the frequent washout of microorganisms, inhibited digestion and unstable fermentation processes (Angelidaki and Ahring 1994; Weiland 2010).

Furthermore, it is crucial to maintain constant temperature during the fermentation processes as methanogens are likely to be affected by sudden temperature changes. Any temperature changes or fluctuations can adversely influence the biogas production. Thermophilic microbes are more sensitive to temperature fluctuations and require longer time to adapt to a new temperature, while mesophilic bacteria tolerate temperature fluctuations of $+/-3{ }^{\circ} \mathrm{C}$ without significant reductions in methane production (Weiland 2010; Garba 1996).

Although the drop in temperature can result in the reduction of methane production, it may shift the proportion of methane in the biogas. Martinez-Sosa et al. (2011) mentioned that an increase in methane composite in the biogas was observed when the operational temperature of SAnMBR dropped from mesophilic $\left(35^{\circ} \mathrm{C}\right)$ to transition condition $\left(28{ }^{\circ} \mathrm{C}\right)$, and this increase was more obvious when the temperature was further reduced to psychrophilic (from 28 to $20^{\circ} \mathrm{C}$ ). This change in the biogas composition could be explained by the difference in gas solubility of two gases $\left(\mathrm{CH}_{4}\right.$ and $\left.\mathrm{CO}_{2}\right)$. Based on Henry's Law, the solubility of methane in water is 11.4 times lower than that of $\mathrm{CO}_{2}$ considering partial pressures of methane and $\mathrm{CO}_{2}$ of 70 and $30 \mathrm{kPa}$, respectively, at $20{ }^{\circ} \mathrm{C}$. Thus, $\mathrm{CO}_{2}$ was dissolved in a major proportion in the liquid phase of the reactor and left the reactor dissolved in the effluent. Nevertheless, the solubility of methane also increases with decreasing temperature, and in fact, the solubility of methane at $20{ }^{\circ} \mathrm{C}$ is around $30 \%$ higher than that at $35{ }^{\circ} \mathrm{C}$. Therefore, a higher amount of methane could leave the anaerobic reactor in the form of dissolved gas in the effluent under psychrophilic conditions, which eventually cause decrease in overall methane production.

Gao et al. (2011) have also investigated the effects of temperature and temperature shock on the performance of a SAnMBR treating thermomechanical pulping pressate for 416 days. The results showed that the SAnMBR system was highly resilient to temperature variations in terms of COD removal. The residual COD in the treated effluent was slightly higher at $55^{\circ} \mathrm{C}$ than those at 37 and $45^{\circ} \mathrm{C}$, but the removal efficiency was within the range of $76-83 \%$ in three cases. At 37,45 
and $55^{\circ} \mathrm{C}$ steady state, there were no significant changes in biogas production rate as well as biogas composition, and the biogas production rates were $0.21 \pm 0.03,0.20 \pm$ 0.03 and $0.21 \pm 0.02 \mathrm{~L} \mathrm{CH}_{4} / \mathrm{gCOD}$ removed, respectively. On the other hand, temperature shocks led to a temporary increase in biogas generation rate. Although the SAnMBR could tolerate the 5 and $10{ }^{\circ} \mathrm{C}$ temperature shocks at $37{ }^{\circ} \mathrm{C}$ and the temperature variations from 37 to $45^{\circ} \mathrm{C}$, the temperature shock of 5 and $10{ }^{\circ} \mathrm{C}$ at 45 ${ }^{\circ} \mathrm{C}$ led to slight and significant disturbance of the performance, respectively. Thus, larger magnitudes $\left(10^{\circ} \mathrm{C}\right)$ of temperature shock had a more severe impact on the performance of the SAnMBR. In addition, Temperature shocks had little effect on the microbial community structure. However, increasing the operating temperature induced the deflocculation of the large sludge flocs, and the diversity and species richness could be affected by temperature variations.

pH. During anaerobic fermentation, $\mathrm{pH}$ variation has been reported to exert significant impact on the microbial metabolism, such as utilization of carbon and energy sources, efficiency of substrate degradation, synthesis of proteins and various types of storage materials, and release of metabolic products from cells. Moreover, $\mathrm{pH}$ variation can also affect cell morphology and structure, as well as flocculation and adhesion phenomena (Bailey and Ollis 1986; Gottschalk 1986; Yadvika et al. 2004). Weiland (2010) have stated that methane formation takes place from about 6.5 to 8.5 with an optimum interval between 7.0 and 8.0. The process is severely inhibited if the pH decreases below 6.0 or rises above 8.5. Nevertheless, Ward et al. (2008) have had little different opinion and indicated that the optimum $\mathrm{pH}$ for anaerobic digestion appears to be $6-8$. The ideal $\mathrm{pH}$ range for anaerobic digestion is very narrow, which ranges between 6.8 and 7.2 by feeding at an optimum loading rate. The growth rate of methanogens is severely inhibited when $\mathrm{pH}$ falls below 6.6, while an excessively alkaline $\mathrm{pH}$ (above 8.5) can lead to disintegration of microbial granules and subsequent failure of the process. Although the optimal $\mathrm{pH}$ of methanogenesis is around $\mathrm{pH}$ 7.0, the optimum $\mathrm{pH}$ for hydrolysis and acidogenesis has been reported between $\mathrm{pH} 5.5$ and 6.5. This is an important reason why some designers prefer the separation of the hydrolysis/acidification and acetogenesis/methanogenesis processes in two-stage processes.

Till now, AnMBRs have been operated at the $\mathrm{pH}$ range of 5.5-8.2 according to different treatment purposes and characteristics of the wastewaters. Most AnMBR systems operate at near neutral $\mathrm{pH}$, and such a $\mathrm{pH}$ range is usually maintained through neutralization, which could require the excessive use of chemicals. Normally, as hydrolysis and acidogenesis phases decrease $\mathrm{pH}$ values, equalization at a desired $\mathrm{pH}$ appears to be a prospective solution although related research was very limited in AnMBR systems. Moreover, the extreme $\mathrm{pH}$ conditions in some streams (e.g. industrial wastewaters) not only damage biologic performance, but also affect membrane permeability and lifespan (Lin et al. 2013).

Commonly, the $\mathrm{pH}$ value increases by ammonia accumulation during degradation of proteins while the accumulation of VFA decreases the $\mathrm{pH}$ value. However, the accumulation of VFA will not always contribute to a $\mathrm{pH}$ drop because 
of the buffer capacity of the substrate. For example, animal manure has a surplus of alkalinity, which stabilizes the $\mathrm{pH}$ value at VFA accumulation. Although acetic acid is usually present in higher concentrations than other fatty acids, but propionic and butyric acids have a more inhibitory effect on methanogens. As a result, as a key intermediate in the process, VFA are capable of inhibiting methanogenesis in high concentrations, and the inhibiting effect of VFAs is much higher in AnMBR operating at low $\mathrm{pH}$ value (Weiland 2010)

Jane Gao et al. (2010) carried out a 120-day study to investigate the impact of elevated $\mathrm{pH}$ shocks $(\mathrm{pH} 8.0,9.1$ and 10.0) on a SAnMBR for thermomechanical whitewater treatment. The results showed that a $\mathrm{pH} 8.0$ shock had a minor impact, whereas $\mathrm{pH} 9.1$ and 10 shocks had significantly long-lasting negative effects on COD removal, biogas production and membrane performance of the SAnMBR. During $\mathrm{pH}$ 9.1 and 10.0 shocks, the COD removal efficiency was dramatically decreased from almost $90 \%$ to $<75 \%$ and from $90 \%$ to $<30 \%$, respectively. Regarding the biogas production rates, the methane generation was slightly reduced from $0.41 \pm 0.04$ to $0.38 \pm 0.07 \mathrm{~L} \mathrm{CH}_{4} / \mathrm{gCOD}$ removed when the $\mathrm{pH}$ increased from 7.0 to 8.0. However, the biogas production rates were sharply decreased to almost 0 as a response to the $\mathrm{pH} 9.1$ and 10.0 shocks. The gas composition was also remarkably affected by $\mathrm{pH}$ shocks. At $\mathrm{pH} 7.0$, the gas phase was composed of about $68 \% \mathrm{CH}_{4}$ and $25 \% \mathrm{CO}_{2}$ with $\mathrm{N}_{2}$ as the main remainder gas. After the reactor had received a $\mathrm{pH} 8.0$ shock, the $\mathrm{CH}_{4} / \mathrm{CO}_{2}$ ratio was slightly reduced from 2.7 to 2.1 , and recovered within 2 days. Further increased $\mathrm{pH}$ shocks resulted in a significant reduction of $\mathrm{CH}_{4} / \mathrm{CO}_{2}$ and a longer recovery period. When the normal $\mathrm{pH}$ (7.0) was resumed, it took approximately 1, 6, and 30 days for the performance of AnMBR to recover for $\mathrm{pH} 8.0$, 9.1 and 10.0 shocks, respectively. Moreover, with the $\mathrm{pH} 10.0$ shock, it exhibited a lower biogas yield $\left(0.35 \pm 0.02\right.$ vs $0.41 \pm 0.01 \mathrm{~L} \mathrm{CH}_{4} / \mathrm{gCOD}$ removed before the $\mathrm{pH}$ 10.0 shock) after the process ran stably. Chemical analysis showed that the ammonia concentration in the mixed liquor $(36.5 \mathrm{mg} / \mathrm{L})$ was significantly higher than that $(21.8$ $\mathrm{mg} / \mathrm{L}$ ) in the feed, implying the accumulation of ammonia in the mixed liquor was caused by biomass death or decay after the $\mathrm{pH} 10.0$ shock. In addition, the elevated $\mathrm{pH}$ shocks induced the dispersion of sludge flocs and resulted in the accumulation of colloids and solutes or biopolymers in the sludge suspension, and thus deteriorated membrane performance. Statistical analysis showed that the lower ratio of proteins (PN) to polysaccharides (PS) in extracellular polymeric substances (EPS) had a strongly negative effect on the membrane fouling rate. There were smaller size particles deposited on the membrane surface and a more compact and denser cake layer was formed after being exposed to an alkaline shock at $\mathrm{pH} 10$, resulting in higher membrane fouling rates.

HRT and SRT. As two key operational parameters, HRT and SRT are controllable and make contributions to different treatment performance and biomass characteristics. For example, lower HRTs mean smaller reactor, and lower cost, while longer SRTs potentially result in higher soluble COD removal, lower sludge yields for disposal and more methane production (Stuckey 2012). For the conventional anaerobic digestion processes which do not decouple SRT from HRT, long SRTs are 
necessary to retain slow-growth anaerobic microorganisms, and thus reduce their competitiveness. In contrast, SRT is independent of HRT in AnMBRs, thereby providing easy control of SRT (Van Haandel and Lettinga 1994; Liao et al. 2006; Trzcinski and Stuckey 2010; Stuckey 2012).

In principle, AnMBRs operation with relatively long HRTs and SRTs are favorable, in order to enhance methane recovery and reduce sludge production. However, prolonged HRT may only be able to improve pollutants removal with a limited extent. On one hand, although HRTs of AnMBR (generally $>8 \mathrm{~h}$ ) are longer than those of aerobic MBR (generally 4-8 h), they are compared favorably with conventional anaerobic systems. According to review of Lin et al. (2013), the applied HRTs in AnMBR varied from $2.6 \mathrm{~h}$ to $14 \mathrm{~d}$, while the typical HRTs for high strength wastewater treatment and dilute wastewater treatment were $1-10 \mathrm{~d}$ and $0.25-2 \mathrm{~d}$, respectively. However, for treating the high-solid-content streams, the applied HRT range of AnMBR is usually higher than the range applied in industrial or municipal wastewater treatment, which ranges at $1.5-11.8 \mathrm{~d}$. This indicated that for particulate stream treatment, a relatively long HRT may be necessary to ensure significant hydrolysis of solid matters. On the other hand, although SRT can determine both treatment performance and membrane fouling of AnMBR, the relationship between SRT and treatment performance or membrane fouling is complex, and highly depends on the applied HRT and the feed characteristics. Normally, since hydrolysis or solubilization stage represents the rate-limiting step in the anaerobic degradation of most solid organic materials, long SRTs are required for hydrolysis proceeds completely at optimal conditions. The applied SRTs in AnMBR, however, are significantly higher than the applied HRTs. In case of municipal wastewater treatment, SRTs have ranged from 19 to $217 \mathrm{~d}$, while for high-solid-content wastes, the SRTs have been employed with a range of 20-335 d (Liao et al. 2006; Lin et al. 2013).

Ho and Sung (2009) studied a lab-scale external AnMBR to treat synthetic municipal wastewater (OLR: $\left.1-2 \mathrm{kgCOD} / \mathrm{m}^{3} \cdot \mathrm{d}\right)$ at different HRTs $(6,8$ and $12 \mathrm{~h})$ for $280 \mathrm{~d}$. They concluded that AnMBR operation with relatively long SRTs (90-360 d) and low crossflow velocity $(0.1-0.2 \mathrm{~m} / \mathrm{s})$ could reduce sludge production. The effluent quality was excellent regardless of HRT variation and COD concentration was always lower than $40 \mathrm{mg} / \mathrm{L}$ ( $>90 \%$ removal). However, the fraction of methane recovered from the synthetic wastewater decreased from 48 to $35 \%$ with the decrease of HRT from 12 to $6 \mathrm{~h}$, which was attributed to the increase of mixed liquor soluble COD accumulated in the AnMBR. Maximum possible methane recovery $(0.22 \mathrm{~L}$ $\mathrm{CH}_{4} / \mathrm{gCOD}$ removed), considering methane solubility, sulfate reduction and cell synthesis, was approximately 50 to $60 \%$ at the longest HRT of $12 \mathrm{~h}$.

Huang et al. (2011) evaluated the effects of different SRTs (30, 60 and infinite d) and HRTs $(12,10$ and $8 \mathrm{~h})$ on the performance of three SAnMBRs for synthetic low-strength wastewater treatment. Total COD removals higher than $97 \%$ were achieved at all operating conditions. Maximum biogas production rate was $0.056 \mathrm{~L}$ $\mathrm{CH}_{4} / \mathrm{gMLVSS} \cdot \mathrm{d}$ at the infinite SRT. The results also elucidated that shorter HRT or 
longer SRT could promote biogas production due to increased OLR or improved dominance of methanogens. However, shorter HRT enhanced biomass growth and SMP accumulation, which accelerated membrane fouling. In spite of higher carbohydrate and protein concentrations in SMP at longer SRT can lead to higher membrane fouling rate, the effect of SRT on biomass concentration in SAnMBRs was negligible and membrane fouling was controlled at the longest HRT (12 h). Nevertheless, at 8 and 10-h HRTs, infinite SRT in SAnMBR caused highest MLSS and SMP concentrations, which accelerated particle deposition and biofouling development. Additionally, lower bounded EPS at longer SRT reduced flocculation of particulates and particle sizes, further aggravated membrane fouling.

\subsection{Future Perspectives and Research Needs for AnMBR Technology}

The review of literature has revealed that much progress has been made in the research and applications of AnMBRs as a future green technology. The key competitive advantages of AnMBRs over conventional aerobic and anaerobic processes have been well documented as follows: 1) total biomass retention; 2) excellent effluent quality; 3) sludge and waste minimization; 4) bioenergy recovery; 5) smaller footprint; 6) lower energy consumption; 7) high efficiency of wastewater treatment; 8) high OLR treatment capacity; 9) strong ability of handling fluctuation in influent quality; 10) high flexibility of treatment mode (either total or pretreatment); and 11) sustainable waste management (Liao et al. 2006; Skouteris et al. 2012; Lin et al. 2013) .

Biogas recovery represents one of the key green features of AnMBR technology, particularly for SAnMBR. The compact configure of SAnMBR allows to collect biogas more conveniently. Through a cost analysis, Lin et al. (2011) revealed a benefit value of US\$341640/year from energy recovery from a full-scale AnMBR, which was about 1.5 times of the annual operational costs. This indicated that it was possible to operate a SAnMBR not only at low costs, but also to create benefit of biogas recovery. However, how to control the system to achieve optimized biogas production is an immediate goal for AnMBR. Till now, the process control systems available for monitoring both hydrolysis and fermentation processes have not been successfully applied at the commercial scale due to the complexity for the consortia of organisms. To develop better spectroscopic sensors, gas sensors, the software sensor approach and generic process model are needed to conduct real time measurements, as well as predict important parameters (e.g. $\mathrm{pH}$, temperature or VFA) that incorporate optimal biogas production (Ward et al. 2008; Lin et al. 2013).

Moreover, the results of recent research have demonstrated that strong variations in the community structures occur during the ongoing fermentation process, which influences the process efficiency. Recent molecular analyses have also illustrated the presence of numerous unknown bacteria that may have an important impact on the degradation process (Weiland 2010). Therefore, research on microbial 
community structure and the influence of the microbial community structure on process stability are also of significance to accomplish kinetic perspective-based improvement of biogas production.

In addition, the development of effective and economical methane recovery process (i.e. reactor design, applying co-digestion, pretreatment of substrates, addition of micronutrients and improving mixing characteristics) also needs attention in order to further improve economic feasibility of AnMBR for real wastewater treatment. Importantly, a study on development multi-stage hybrid AnMBR systems will be promising for future wastewater treatment. Such a process would combine the benefits of anaerobic digestion (i.e. biogas production), aerobic degradation (i.e. nutrient removal) and membrane separation (i.e. pathogen and micropollutants removal). As an increased methane yield and reduced HRT can be fulfilled by increasing the microbial density by immobilization, AnMBR combined with the attached-growth (biofilm) process seems to have great potential advantages of improving process efficiency and reducing fermentation failure.

So far, most literature has been focused on the research on bench-scale AnMBRs; further research of larger scale AnMBRs is needed for their wide implementation for municipal or industrial sectors. Nevertheless, AnMBR has always been facing another crucial challenge of membrane fouling and its consequences, which are not discussed in this chapter due to extensively existing reviews. In spite of the obvious key advantages, membrane fouling of AnMBR remains as a main challenge for its worldwide applications, especially associated with its economic consequences in terms of plant maintenance and operation costs (Lin et al. 2013). Although the comprehensive investigations on membrane fouling mechanisms and fouling control in AnMBRs have been undertaken with intensive efforts, further research is still needed to look for more feasible and easier fouling mitigation measures. High membrane cost is also a critical issue hindering the faster commercialization of AnMBRs, even though the cost of MF and UF membranes used in the majority of projects has been dramatically reduced in recent years. Skouteris et al. (2012) reported that the cost of membranes appear to be up to 10 times higher than the energy consumption cost per $\mathrm{m}^{3}$ of treated water, and thus can significantly reduce economic affordability and attractiveness. Moreover, Lin et al. (2011) stated that cost analysis of the full-scale SAnMBR system indicated that membrane costs and gas scouring energy accounted for the largest fraction of total life cycle capital costs and operational costs, respectively. Although the operational costs can be totally offset by the benefits from biogas recovery, sensitive analysis showed that membrane parameters including flux, price and lifetime play decisive roles in determining the total life cycle costs of the SAnMBR. Therefore, efforts aiming at developing low costs and better performance membranes for AnMBRs are greatly appreciated so as to increase their economic sustainability. 


\subsection{Conclusion}

The critical analysis in this chapter provides detailed information about the state-of-the-art development and applications of the AnMBR technology in wastewater treatment. In general, AnMBRs have great potential to efficiently treat a rich variety of wastewaters, producing high-quality effluent ready for recycling or reuse. As a promising future green technology, the biogas recovery in AnMBR not only promote the reduction of greenhouse gases emission but also can fulfill the heating requirements of wastewater treatment plant instead of using fossil fuel. The complex digestion occurring in AnMBR is significantly influenced by many factors such as wastewater characteristics, temperature, $\mathrm{pH}$, HRT, SRT, OLR, nutritional requirements and so on. Among these factors, temperature, $\mathrm{pH}$, HRT and SRT play important roles in biogas production and process stability. In addition, the opportunity of applying such green technology at large- or commercial-scale needs prospective studies to conquered many research challenges such as biogas recovery, better process control, process efficiency, membrane cost, membrane fouling as well as economic issues.

\subsection{References}

Ali, M., and Sreekrishnan, T. R. (2001). "Aquatic toxicity from pulp and paper mill effluents: a review." Advance in Environmental Research, 5, 175-196.

Anderson, G. K., Kasapgil, B., and Ince, O. (1996). "Microbial kinetics of a membrane anaerobic reactor system." Environmental Technology, 17, 449464.

Angelidaki, I., Ellegaard, L., and Ahring, B. K. (1993). "A mathematical model for dynamic simulation of anaerobic digestion of complex substrates:focusing on ammonia inhibition." Biotechnology Bioengineering, 42, 159-166.

Angelidaki, I., and Ahring, B. K. (1994). "Thermophilic anaerobic digestion of livestock waste: the effect of ammonia." Applied Microbiology Biotechnology, 38(4), 560-564.

Ankley, G. T., Black, M. C., Garric, J., Hutchinson, T. H., and Iguchi, T. (2005). A framework for assessing the hazard of pharmaceutical materials to aquatic species, In: Williams, R.T. (Ed.), Human Pharmaceuticals-Assessing the Impacts on Aquatic Ecosystems. SETAC Press, SETAC Brussels, Belgium, pp. 183-237.

Athanasopoulos, N. (1992). "Cotton yarn and fabric finishing wastewater treatment using an anaerobic expanded bed reactor." Bioresource Technology, 39, 291293.

Baek, S. H., and Pagilla, K. R. (2006). "Aerobic and anaerobic membrane bioreactors for municipal wastewater treatment." Water Environment Research, 78, 133140.

Baêta, B. E. L., Ramos, R. L., Lima, D. R. S., and Aquino, S. F. (2012). "Use of submerged anaerobic membrane bioreactor (SAMBR) containing powdered 
activated carbon (PAC) for the treatment of textile effluents." Water Science and Technology, 65(9), 1540-1547.

Bagi Z., Ács, N., Bálint, B., Horváth, L., Dobó, K., Perei, K. R., Rákhely G., and Kovács, K. L. (2007). "Biotechnological intensification of biogas production." Applied Microbiology Biotechnology, 76, 473-482.

Bailey, J. E., and Ollis, D. F. (1986). Biochemical Engineering Fundamentals, 2nd Ed., McGraw-Hill.

Brockmann, M. and Seyfried, C. F. (1996). "Sludge activity and cross-flow microfiltration - a non-beneficial relationship." Water Science and Technology, 34(9), 205-213.

Chan. Y. J., Chong, M. F., Law, C. L., and Hassell, D. G. (2009). "A review on anaerobic-aerobic treatment of industrial and municipal wastewater." Chemical Engineering Journal, 155(1-2), 1-18.

Chen, Y. R., and Hashimoto, A. G. (1980). "Substrate utilization kinetic model for biological treatment process." Biotechnology Bioengineering, 22, 2081-2095.

Chen, Y., Cheng, J. J., and Creamer, K. S. (2008a). "Inhibition of anaerobic digestion process: A review." Bioresource Technology, 99, 4044-4064.

Chen, Z., Ren, N. Q., Wang, A. J., Zhang, Z. P., and Shi, Y. (2008b). "A novel application of TPAD-MBR system to the pilot treatment of chemical synthesis-based pharmaceutical wastewater." Water Research, 42, 3385-3392.

Choo, K., and Lee, C. H. (1998). "Hydrodynamic behavior of anaerobic biosolids during crossflow filtration in the membrane anaerobic bioreactor." Water Research, 32, 3387-3397.

Chou, W. L., Speece, R. E., Siddiqi, R. H., and McKeon, K. (1978). "The effect of petrochemical structure on methane fermentation toxicity." Progress in Water Technology, 10 (5/6), 545-558.

De Lemos Chernicharo C. A. (2007). Anaerobic Reactors: Biological Wastewater Treatment Volume 4 (Biological Wastewater Treatment Series), IWA Publishing, UK.

Demirel, B., Scherer, P., Yenigun, O., and Onay, T. T. (2010). "Production of methane and hydrogen from biomass through conventional and high-rate anaerobic digestion processes." Critical Reviews in Environmental Science and Technology, 40, 116-146,

Dereli R. K., Ersahin M. E., Ozgun, H., Ozturk, I., Jeison, D., van der Zee, F., and van Lier, J. B. (2012). "Potentials of anaerobic membrane bioreactors to overcome treatment limitations induced by industrial wastewaters. "Bioresource Technology, 122, 160-170.

Du Preez, J., Norddahl, B., and Christensen, K. (2005). "The BIOREK ${ }^{\circledR}$ concept: a hybrid membrane bioreactor concept for very strong wastewater." Desalination, 183, 407-415.

Elmitwalli, T. A., Soellner, J., De Keizer, A., Bruning, H., Zeeman, G., and Lettinga, G. (2001). "Biodegradability and change of physical characteristics of particles during anaerobic digestion of domestic sewage." Water Research, 35, 1311-1317.

Enick, O. V., and Moore, M. M. (2007). "Assessing the assessments: pharmaceuticals in the environment." Environment Impact Assessment Review, 27, 707-729. 
Feitkenhauer, H. (2004). "Fast online determination of surfactant inhibition in acidic phase bioreactors." Water Science Technology, 49(1), 23-29.

Fent, K., Weston, A. A., and Caminada, D. (2006). "Ecotoxicology of human pharmaceuticals." Aquatic Toxicology, 76, 122-159.

Gander, M., Jefferson, B., and Judd, S. (2000). "Aerobic MBRs for domestic wastewater treatment: a review with cost considerations." Separation and Purification Technology, 18, 119-130.

Gao, W. J., Leung, K. T., Qin, W. S., and Liao, B. Q. (2011). "Effects of temperature and temperature shock on the performance and microbial community structure of a submerged anaerobic membrane bioreactor." Bioresource Technology, 102, 8733-8740.

Garba, B. (1996). "Effect of temperature and retention period on biogas production from ligro cellulosic material." Renewable Energy, 9(1-4), 938-941.

Gottschalk, G. (1986). Bacterial metabolism, 2nd Ed., Springer-Verlag, New York.

Grethlein, H. E. (1978). "Anaerobic digestion and membrane separation of domestic wastewater." Journal of the Water Pollution Control Federation, 50(4), 754 763.

Guo, W. S., Ngo, H. H., Dharmawan, F., and Palmer, C. G. (2010). "Roles of polyurethane foam in aerobic moving and fixed bed bioreactors." Bioresource Technology, 101, 1435-1439.

Guo, W. and Ngo, H. (2012). "Membrane Processes for Wastewater Treatment." Membrane Technology and Environmental Applications, Zhang, T.C., Surampalli, R.Y., Vigneswaran, S., Tyagi, R.D., Ong, S.L. and Kao, C.M. (Eds.), American Society of Civil Engineers (ASCE), USA, 169-216.

Ho, J., and Sung, S. (2009). "Anaerobic membrane bioreactor treatment of synthetic municipal wastewater at ambient temperature." Water Environmental Resource, 81(9), 922-928.

Hogetsu, A., Ishikawa, T., Yoshikawa, M., Tanabe, T., Yudate, S., and Sawada, J. (1992). "High rate anaerobic digestion of wool scouring wastewater in a digester combined with membrane filter." Water Science Technology, 25(7), 341-350.

Huang, Z., Ong, S. L., and Ng, H. Y. (2011). "Submerged anaerobic membrane bioreactor for low-strength wastewater treatment: effect of HRT and SRT on treatment performance and membrane fouling." Water Research, 45, 705-713.

Ifelebuegu, A. O. (2011). "The fate and behavior of selected endocrine disrupting chemicals in full-scale wastewater and sludge treatment unit processes." International Journal of Environmental Science and Technology, 8, 245-254.

Ince, K. B., Selcuk, A., and Ince, O. (2002). "Effect of a chemical synthesis -based pharmaceutical wastewater performance, acetoclastic methanogenic activity and microbial population in an upflow anaerobic filter." Journal of Chemical Technology and Biotechnology, 77, 711-719.

Ivanovic, I., and Leiknes, T. O. (2012). "The biofilm membrane bioreactor (BF-MBR) - a review." Desalination and Water Treatment, 37, 288-295.

Jane Gao, W. J., Lin, H. J., Leung, K. T., and Liao, B. Q. (2010). "Influence of elevated $\mathrm{pH}$ shocks on the performance of a submerged anaerobic membrane bioreactor." Process Biochemistry, 45, 1279-1287. 
Kanai, M., Ferre, V., Wakahara, S., Yamamoto, T., and Moro, M. (2010). "A novel combination of methane fermentation and MBR - Kubota Submerged Anaerobic Membrane Bioreactor process.” Desalination, 250 964-967.

Kataoka, N., Tokiwa, Y., Tanaka, Y., Fujiki, K., Taroda, H., and Takeda, K. (1992). "Examination of bacterial characteristics of anaerobic membrane bioreactors in three pilot-scale plants for treating low strength wastewater by application of colony forming curve analysis method." Applied and Environmental Microbioloy, 58, 2751-2757.

Kimura, S. (1991). “Japan's aqua renaissance '90 project.” Water Science Technology, 23(7-9), 1573-1582.

Kiriyama, K., Tanaka, Y., and Mori, I. (1992). "Field test of a composite methane gas production system incorporating a membrane module for municipal sewage." Water Science and Technology, 25(7), 135-141.

Kiriyama, K., Tanaka, Y., and Mori, I. (1994). "Field test on a methane fermentation treatment system incorporating a membrane module for municipal sewage." Desalination, 98, 199-206.

Kleerebezem, R., and Macarie, H. (2003). "Treating industrial wastewater: Anaerobic digestion comes of age." Chemical Engineering, April, 56-64.

Kujawa-Roeleveld, K. (2008). Biodegradability and fate of pharmaceutical impact compounds in different treatment processes. Available at http://www.switchurbanwater.eu/outputs/pdfs/W41_GEN_RPT_D4.1.3 Biod egradability and fate of phamarceutical compounds.pdf (Accessed on Sep. 1, 2013).

Lang, X. M. (2006). "Pharmaceutical wastewater treatment with hydrolysis acidifying-UNITANK-BAF process." Ph.D. Thesis, Northeast University, China, 1-12.

Lee, S. M., Jung, J. Y., and Chung, Y. C. (2001). "Novel method for enhancing permeate flux of submerged membrane system in two phase anaerobic reactor." Water Research, 35, 471-477.

Lee, Y. H., and Pavlostathis, S. G. (2004). "Reuse of textile reactive azo dyebaths following biological decolorization." Water Environment Resource, 76(1), 56-66.

Lettinga, G., Rebac, S., and Zeeman, G. (2001). "Challenge of psychrophilic anaerobic wastewater treatment." Trends in Biotechnology, 19(9), 363-370.

Lew, B., Belavski, M., Admon, S., Tarre S., and Green, M. (2003). "Temperature effect on UASB reactor operation for domestic wastewater treatment in temperate climate regions." Water Science Technology, 48(3), 25-30.

Lew, B., Tarre, S., Beliavski, M., Dosoretz, C., and Green, M. (2009). "Anaerobic membrane bioreactor (AnMBR) for domestic wastewater treatment." Desalination, 243, 251-257.

Li, A., Kothari, D., and Corrado, J. J. (1985). "Application of membrane anaerobic reactor system for the treatment of industrial wastewaters." Proceedings of the $39^{\text {th }}$ Industrial Waste Conference, Purdue University, Ann Arbor Science, Ann Arbor, MI, 627-636. 
Liao, B. Q., Kraemer, J. T., and Bagley, D. M. (2006). "Anaerobic membrane bioreactors: Applications and research directions." Critical Reviews of Environmental Science and Technology, 36, 489-530.

Liao, B. Q., Xie, K., Lin, H. J., and Bertoldo, D. (2010). "Treatment of kraft evaporator condensate using a thermophilic submerged anaerobic membrane bioreactor." Water Science Technology, 61, 2177-2183.

Lin, H. J., Xie, K., Mahendran, B., Bagley, D. M., Leung, K. T., Liss, S. N., and Liao, B. Q. (2009). "Sludge properties and their effects on membrane fouling in submerged anaerobic membrane bioreactors (SAnMBRs)." Water Research, $43,3827-3837$.

Lin, H. J., Chen, J. R., Wang, F. Y., Ding, L. X., and Hong, H. C. (2011). "Feasibility evaluation of submerged anaerobic membrane bioreactor for municipal secondary wastewater treatment." Desalination, 280, 120-126.

Lin, H., Gao, W., Meng. F., Liao, B. Q., Leung K. T., Zhao, L., Chen, J., and Hong, H. (2012). "Membrane bioreactors for industrial wastewater treatment: A critical review." Critical Review of Environmental Science Technology, 42, 677-740.

Lin, H., Peng, W., Zhang, M., Chen, J., Hong, H., and Zhang, Y. (2013). "A review on anaerobic membrane bioreactors: Applications, membrane fouling and future perspectives." Desalination, 314, 169-188.

Luostarinen, S.A. (2005). Anaerobic on-site wastewater treatment at low temperature. Department of Biological and Environmental Science, University of Jyväskylä, Finland. 85 p, available at https://jyx.jyu.fi/dspace/bitstream/handle/123456789/ 13169/951392274X.pdf?sequence=1 (Accessed on 10 August, 2013).

Martinez-Sosa, D., Helmreich, B., Netter, T., Paris, S., and Bischof, F. (2011). "Anaerobic submerged membrane bioreactor (AnMBR) for municipal wastewater treatment under mesophilic and psychrophilic temperature conditions." Bioresource Technology, 102, 10377-10385.

Martinez-Sosa, D., Helmreich, B., and Horn, H. (2012). "Anaerobic submerged membrane bioreactor (AnMBR) treating low-strength wastewater under psychrophilic temperature conditions." Process Biochemistry, 47, 792-798.

McKeown R. M., Hughes, D., Collins, G., Mahony, T., and O'Flaherty, V. (2011). "Low-temperature anaerobic digestion for wastewater treatment." Current Opinion in Biotechnology, 23(3), 444-451.

McMahon, J. (2010). Anaerobic membrane bioreactor system treats high strength wastewater. Available at http://www.waterworld.com/articles/mem/articles /print/volume-2/issue-3/feature/anaerobic-membrane-bioreactor-system-treats -high-strength-wastewater.html (accessed on May 20, 2013).

Minami, K., Okamura, K., Ogawa, S., and Naritomi, T. (1991). "Continuous anaerobic treatment of wastewater from a kraft pulp mill." Journal of Fermentation and Bioengineering, 71(4), 270-274.

Minami, K. (1994). "A trial of high performance anaerobic treatment on wastewater from Kraft pulp and mill." Desalination, 98, 273-283. 
Minami, K., Okamura, K., Ogawa, S., and Naritomi, T. (1991). "Continuous anaerobic treatment of wastewater from a Kraft pulp mill." Journal of Fermentation and Bioengineering, 71(4), 270-274.

Ngo, H., Guo, W., and Vigneswaran, S. (2012). "Membrane Processes for Water Reclamation and Reuse." Membrane Technology and Environmental Applications, Zhang, T.C., Surampalli, R.Y., Vigneswaran, S., Tyagi, R.D., Ong, S.L. and Kao, C.M. (Eds.), American Society of Civil Engineers (ASCE), USA, 239-275.

Niekerk, M. V., Augustyn, M. P., and Van, P. J. (2009). “Anaerobic membrane bioreactor for the treatment of a high strength, low $\mathrm{pH}$ industrial wastewater: preliminary pilot scale investigations." Conference Proceedings IWA MTC 2009, Beijing, China.

Norddahl, B., and Rohold, L. (2000). “The Biorek ${ }^{\circledR}$ concept for the conversion of organic effluent to energy, concentrated fertilizer and potable water." $1^{\text {st }}$ World Conference and Exhibition on Biomass for Energy and Industry, Sevilla, Spain, $5 \square 9$ June, James \& James (Science Publishers) Ltd., Vol. 2, 1529-1532.

Okamura, K., Ogoshi, T., Fujioka, T. and Inoue, G. (1994). “Anaerobic treatment of pulp paper wastewater-Results of Aqua Renaissance 90." Japan Tappi Journal, 48, 1-161.

Oktem, Y. A., Ince, O., Sallis, P., Donnelly, T., and Ince, B. K. (2007). “Anaerobic treatment of a chemical synthesis-based pharmaceutical wastewater in a hybrid upflow anaerobic sludge blanket reactor." Bioresource Technology, 99, 1089-1096.

Owen, S. F., Giltrow, E., Huggett, D. B., Hutchinson, T. H., Saye, J., Winter, M. J., and Sumpter, J. P. (2007). "Comparative physiology, pharmacology and toxicology of b-blockers: mammals versus fish." Aquatic Toxicology, 82, $145-162$.

Oz, A. N., Ince, O., Ince Kasapgil, B., Akarsubasi, A. T., and Eyice, O. (2002). "Microbial population dynamics in an anaerobic CSTR treating chemical synthesis based pharmaceutical waste- water." Journal of Environmental Science Health Part A, 38 (10), 2029-2042.

Ross, W. R., Barnard, J. P., le Roux, J., and de Viliers, H. A. (1990). “Application of ultrafiltration membranes for solids-liquid separation in anaerobic digestion systems: the ADUF process." Water SA, 16 (2), 85-91.

Saddoud, A., Hassaïri, I. and Sayadi, S. (2007). "Anaerobic membrane reactor with phase separation for the treatment of cheese whey." Bioresource Technology, 98, 2102-2108.

Saddoud, A., and Sayadi, S. (2007). "Application of acidogenic fixed-bed reactor prior to anaerobic membrane bioreactor for sustainable slaughterhouse wastewater treatment." Journal of Hazardous Material, 149, 700-706.

Saddoud, A., Abdelkafi, S., and Sayadi, S. (2009). "Effects of domestic wastewater toxicity on anaerobic membrane-bioreactor (MBR) performances." Environmental Technology, 30, 1361-1369.

Saravanane, R., and Sundararaman, S. (2009). "Effect of loading rate and HRT on the removal of cephalosporin and their intermediates during the operation of a 
membrane bioreactor treating pharmaceutical wastewater." Environmental Technology, 30, 1017-1022.

Skouteris, G., Hermosilla, D., Patricio, L., Negro, C., and Blanco, A. (2012). "Anaerobic membrane bioreactors for wastewater treatment: A review." Chemical Engineering Journal, 198-199, 138-148.

Souza C. L., Chernicharo C. A. L., and Aquino S. F. (2010). "Quantification of dissolved methane in UASB reactors treating domestic wastewater under different operating conditions." Proceedings of the 12th World Congress on Anaerobic Digestion, October, Guadalajara, Mexico.

Spagni, A., Casu, S., and Grilli, S. (2012). "Decolourisation of textile wastewater in a submerged anaerobic membrane bioreactor." Bioresource Technology, 117, $180-185$.

Speece, R. E. (1996). Anaerobic Biotechnology for Industrial Wastewaters, Archae Press, Nashville, TN, USA.

Stuckey, D. C. (2012). "Recent developments in anaerobic membrane reactors." Bioresource Technology, 122, 137-148.

Stuckey, D. C., and Hu, A. (2003). "The submerged anaerobic membrane bioreactor (SAMBR): an intensification of anaerobic wastewater treatment." The International Water Association-Leading Edge Conference on Drinking Water and Wastewater Treatment Technologies, IWA, London, Noordwijk/ Amsterdam, Netherlands.

Trzcinski, A. P. and Stuckey, D. C. (2009). "Continuous treatment of the organic fraction of municipal solid waste in an anaerobic two-stage membrane process with liquid recycle." Water Research, 43, 2449-2462.

Trzcinski, A. P. and Stuckey, D. C. (2010) "Treatment of municipal solid waste leachate using a submerged anaerobic membrane bioreactor at mesophilic and psychrophilic temperatures: analysis of recalcitrants in the permeate using GC-MS." Water Research, 44, 671-680.

Uemura, S., and Harada, H., (2000). "Treatment of sewage by a UASB reactor under moderate to low temperature conditions." Bioresource Technology, 72(3), $275-282$.

Van Haandel, A. C., and Lettinga, G. (1994). Anaerobic sewage treatment: a practical guide for regions with a hot climate. Wiley, New York.

Vandevivere, P. C., Bianchi, R., and Verstraete, W. (1998). "Treatment and reuse of wastewater from the textile wet-processing industry: review of emerging technologies." Journal of Chemical Technology and Biotechnology, 72, 289302.

Van Zyl, P. J., Wentzel, M. C., Ekama, G. A., and Riedel, K. J. (2008). "Design and start-up of a high rate anaerobic membrane bioreactor for the treatment of a low $\mathrm{pH}$, high strength, dissolved organic waste water." Water Science and Technology, 57(2), 291-295.

Visvanathan, C., and Abeynayaka, A. (2012). "Developments and future potentials of anaerobic membrane bioreactors (AnMBRs)." Membrane Water Treatment, $3(1), 1-23$. 
Walker M., Banks, C. J., and Heaven S. (2009). "Development of a coarse membrane bioreactor for two-stage anaerobic digestion of biodegradable municipal solid waste." Water Science and Technology, 59(4), 729-735.

Ward, A. J., Hobbs, P. J., Holliman, P. J., and Jones, D. L. (2008). "Optimisation of the anaerobic digestion of agricultural resources." Bioresource Technology, 99, 7928-7940.

Weiland, P. (2010). "Biogas production: current state and perspectives." Applied Microbiology Biotechnology, 85, 849-860.

Wijekoon, K. C., Visvanathan, C., and Abeynayaka, A. (2011). "Effect of organic loading rate of VFA production, organic matter removal and microbial activity of a two-stage thermophilic anaerobic membrane bioreactor." Bioresource Technology, 102, 5353-5360.

Wikipedia (2013). Anaerobic digestion. Available at http://en.wikipedia.org/wiki/Anaerobic_digestion (Accessed on September 5, 2013).

Wong, K., Xagoraraki, I., Wallace, J., Bickert, W., Srinivasan, S., and Rose, J. B. (2009). "Removal of viruses and indicators by anaerobic membrane bioreactor treating animal waste." Journal of Environmental Quality, 38(4), 1694-1699.

Xie, K., Lin, H. J., Mahendran, B., Bagley, D. M., Leung, K. T., Liss, S. N., and Liao, B. Q. (2010). "Performance and fouling characteristics of a submerged anaerobic membrane bioreactor for kraft evaporator condensate treatment." Environmental Technology, 31(5), 511-521.

Yadvika, Santosh, Sreekrishnan, T. R., Kohli, S., and Rana, V. (2004). "Enhancement of biogas production from solid substrates using different techniques - a review." Bioresource Technology, 95, 1-10.

Yanagi, C., Sato, M., and Takahara, Y. (1994). "Treatment of wheat starch wastewater by a membrane combined two phase methane fermentation system." Desalination, 98, 161-170.

Yoo, R., Kim, J., McCarty, P. L., and Bae, J. (2012). "Anaerobic treatment of municipal wastewater with a staged anaerobic fluidized membrane bioreactor (SAF-MBR) system.” Bioresource Technology, 120, 133-139.

Yushina, Y., and Hasegawa, J. (1994). "Process performance comparison of membrane introduced anaerobic digestion using food processing industry wastewater." Desalination, 98, 413-421.

Zhao, C. Y. (2011). Effect of temperature on biogas production in anaerobic treatment of domestic wastewater UASB system in Hammarby SjÖstadsverk. TRITA LWR Degree Project 11:35, Royal Institute of Technology (KTH), Sweden. 